Universidade de São Paulo

Instituto de Psicologia

Carine Savalli Redígolo

\title{
O PAPEL DA ATENÇÃO HUMANA NA COMUNICAÇÃO CÃO-SER HUMANO POR MEIO DE UM TECLADO
}

São Paulo

2008 


\author{
Universidade de São Paulo \\ Instituto de Psicologia \\ Departamento de Psicologia Experimental
}

Carine Savalli Redígolo

\title{
O PAPEL DA ATENÇÃO HUMANA NA COMUNICAÇÃO CÃO-SER HUMANO POR MEIO DE UM TECLADO
}

Dissertação apresentada ao Instituto de Psicologia da Universidade de São Paulo como parte dos requisitos para obtenção do título de mestre.

Área de concentração: Psicologia Experimental Orientador: César Ades

São Paulo

2008 
AUTORIZO A REPRODUÇÃO E DIVULGAÇÃO TOTAL OU PARCIAL DESTE TRABALHO, POR QUALQUER MEIO CONVENCIONAL OU ELETRÔNICO, PARA FINS DE ESTUDO E PESQUISA, DESDE QUE CITADA A FONTE.

Catalogação na publicação

Serviço de Biblioteca e Documentação

Instituto de Psicologia da Universidade de São Paulo

Redígolo, Carine Savalli.

O papel da atenção humana na comunicação cão-ser humano por meio de um teclado / Carine Savalli Redígolo; orientador César Ades. --São Paulo, 2008.

$89 \mathrm{p}$.

Dissertação (Mestrado - Programa de Pós-Graduação em Psicologia. Área de Concentração: Psicologia Experimental) Instituto de Psicologia da Universidade de São Paulo.

1. Cães 2. Comunicação animal 3. Atenção 4. Canis Familiaris I. Título.

QL795.D6 
Carine Savalli Redígolo

\section{O PAPEL DA ATENÇÃO HUMANA NA COMUNICAÇÃO CÃO-SER HUMANO POR MEIO DE UM TECLADO}

Dissertação apresentada ao Instituto de Psicologia da Universidade de São Paulo como parte dos requisitos para obtenção do título de mestre.

Área de concentração: Psicologia Experimental

Aprovado em: I

Banca examinadora

Prof.

Instituição: Assinatura:

Prof.

Instituição: Assinatura:

Prof.

Instituição: Assinatura: 
À Meggie Lee

“E que a minha loucura seja perdoada...

Porque metade de mim é amor (pelos bichos)...

E a outra metade...

Também..."

"Metade" de Oswaldo Montenegro (adaptado) 


\section{Agradecimentos}

A primeira pessoa a quem eu devo agradecer é o professor César por ter me dado essa chance. Mesmo sabendo que eu vinha de uma área muito diferente ele acreditou que eu seria capaz, com muita dedicação, é claro, de alcançar essa conquista. Sempre muito atencioso, o seu entusiasmo, respeito e curiosidade pelos animais é contagiante.

Um agradecimento especial à minha amiga Clarissa que me incentivou a mandar o primeiro email ao professor César. Foi aí que tudo começou.

Agradeço também ao Fernando que sempre me incentivou e esteve do meu lado nas decisões mais cruciais. Tudo teria sido muito mais difícil sem ele.

Meus pais e meu irmão, como a maioria das outras pessoas, no início acharam uma loucura começar tudo de novo. "Mas você já não tem mestrado e doutorado, para que outro?". Hoje, sabendo o quanto isso é importante para mim, eles me dão total apoio.

Não posso deixar de agradecer Angélica, Thaís e Maria, sempre presentes, enfrentando junto comigo os maiores desafios deste trabalho. Às minhas experimentadoras e amigas, muito obrigada.

Devo agradecer á Sofia e Laila, sem elas essa pesquisa não teria sentido de existir. Muito obrigada também aos seus donos, Alexandre e Rively, pela confiança e apoio. Um agradecimento especial à Meggie Lee e Whisky que estavam sempre do meu lado disputando o meu colo durante todo o tempo que eu passei sentada no sofá estudando! Devo agradecer muito à minha psicóloga Rosana, sempre me ajudando a superar os momentos difíceis e enxergar o que é melhor para mim.

Muitas pessoas continuam achando que sou uma louca por recomeçar... Mas outras, principalmente os meus amigos, reconhecem em mim uma grande motivação, satisfação e realização, e, por isso, me apóiam. Muito obrigada a todos os meus amigos. 
Nunca é tarde para arriscar e recomeçar... É necessário muito esforço, muita dedicação. Mas dedicar-se a estudar os animais foi o que de mais interessante e excitante eu já me propus a fazer até hoje. Tem sido muito gratificante.

E quanto à Estatística, minha área de origem? Bem, ela me acompanhará para onde eu for, e será sempre muito importante, mas daqui para frente o meu mundo é "animal". 


\section{RESUMO}

O estudo da comunicação animal-ser humano mediada por signos arbitrários concentrou-se tradicionalmente em chimpanzés, bonobos, golfinhos e papagaios. O cão doméstico (Canis familiaris), na medida em que adaptado pela domesticação à interação com o ser humano, constitui um modelo interessante para a análise dos processos de comunicação interespecíficos. Sofia, o sujeito do presente estudo, é uma cadela treinada a usar um teclado, pressionando teclas com símbolos arbitrários (lexigramas), para comunicar desejos (Rossi \& Ades, 2008).

A questão examinada aqui foi a capacidade de Sofia levar em conta, quando usa o teclado, os sinais de atenção do ser humano e o acesso visual deste ao teclado. Para tanto, foram realizadas três séries de experimentos. Na primeira série de experimentos Sofia devia escolher entre dois teclados idênticos, a partir do aspecto dos experimentadores que permaneciam em frente a cada um deles: (1) condição de orientação corporal $(O C)$ : um experimentador de frente, outro de costas; (2) condição de visibilidade dos olhos (VO): um experimentador com venda nos olhos, outro sem venda. Numa segunda série de experimentos, Sofia, depois de usar o teclado, devia escolher entre dois experimentadores para receber o pedido, (3) condição OCexp: um experimentador de frente, o outro de costas; (4) condição VOexp: um experimentador com venda nos olhos, o outro sem. Finalmente, na terceira série de experimentos, Sofia devia escolher entre dois teclados, um deles situado atrás de um anteparo opaco, fora do campo de visão do experimentador e o outro visível: (5) condição $A A$ : anteparo opaco alto; (6) condição AB: anteparo opaco baixo; (7) condição AT: anteparo opaco baixo de um lado, anteparo transparente baixo do outro. Sofia não escolheu em proporção 
significativa o teclado próximo aos experimentadores que poderiam vê-la (OC, VO), entretanto escolheu significativamente o experimentador situado de frente a ela (OCexp) para receber o alimento, sem contudo manifestar preferência no caso VOexp, resultados que indicam que Sofia é capaz de levar em conta um sinal de atenção (posição frentecostas) quando se dirige diretamente para o experimentador. Nos experimentos com anteparos, observou-se escolha quase que total da alternativa sem anteparo ou com anteparo transparente (AA, AB e AT), resultado que demonstra a sensibilidade de Sofia à condição de acesso visual do experimentador ao teclado. 


\section{ABSTRACT}

Studies on animal-human being communication through arbitrary signs were traditionally concentrated in chimpanzees, bonobos, dolphins and parrots. The domestic dog (Canis familiaris) constitutes an interesting model for the analysis of interespecific communication processes since it is well adapted by domestication to interact with the human being. Sofia, the subject of the present study, is a mongrel dog trained to press keys on a keyboard with arbitrary signs to communicate her desires (Rossi \& Ades, 2008).

The question here examined was Sofia's capacity of taking into account the human attention signs and his visual access to the keyboard when she uses it. In order to answer these questions three series of experiments were carried out. In the first series, Sofia had to choose between two identical keyboards, based on the experimenter condition that was in front of each keyboard: (1) body orientation condition (OC): one experimenter was facing the keyboard, while the other one was facing backwards; (2) The eye visibility condition (VO): one experimenter had a blindfold covering his eyes, while the other one did not. In the second series of experiments, Sofia, after pressing the keyboard, should choose between two experimenters to receive what she asked for: (3) OCexp condition: one experimenter facing Sofia, and the other one facing backwards; (4) VOexp condition: one experimenter with a blindfold covering his eyes, the other one without it. Finally, in the third series of experiments, Sofia should choose between two keyboards, one of them placed behind an opaque barrier, out-of-view from the experimenter point, and the other one plainly visible for him: (5) $A A$ condition: a high opaque barrier; (6) $A B$ condition: a low opaque barrier and (7) AT condition: a low 
opaque barrier on one side, and a transparent barrier on the other side. Sofia did not choose significantly more the keyboard in front of experimenters that could see her pressing it, in front of her or without a blindfold (OC, VO). However, she chose significantly more the experimenter facing her to receive what she had just asked for (OCexp), although she did not preferred the experimenter without blindfold (VOexp). These results indicate that Sofia is able to take into account the attention signs (body orientation) when she goes directly to the experimenter. In the barrier experiments, she chose for almost all sessions the no-barrier alternative or the transparent barrier (AA, $\mathrm{AB}$ and $\mathrm{AT}$ ), which demonstrate that Sofia is sensitive to the human visual access to the keyboard. 


\section{SUMÁRIO}

INTRODUÇÃO .............................................................................. 14

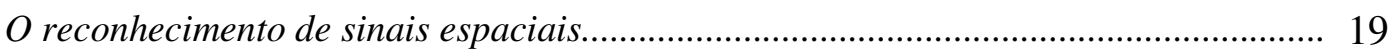

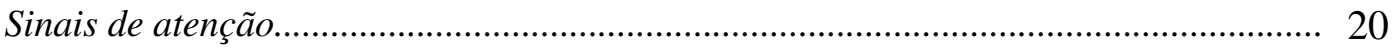

Sinais de atenção e cumprimento de uma ordem......................................................... 23

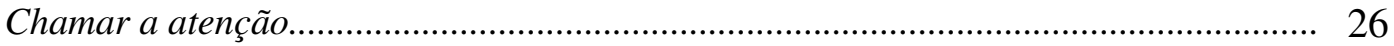

Comunicação por meio de sinais arbitrários.............................................................. 27

O uso de sinais arbitrários pelo cão........................................................................ 30

Influência dos sinais de atenção e do acesso visual humano no uso do teclado por

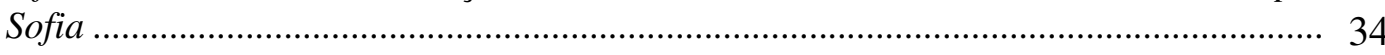

Acesso visual do experimentador (anteparos): escolha do teclado................................ 35

Sinais de atenção visual dos experimentadores (frente $\times$ costas / sem venda $\times$ com venda nos olhos): escolha do teclado ............................................................................. 36

Sinais de atenção visual dos experimentadores (frente $\times$ costas / sem venda $\times$ com venda nos olhos): escolha do experimentador............................................................... 36

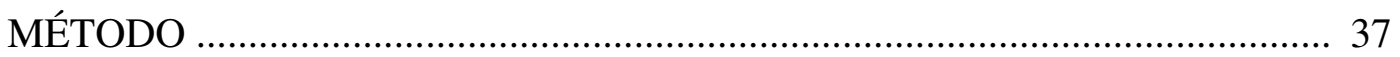

Sujeito experimental, local do estudo e teclados......................................................... 37

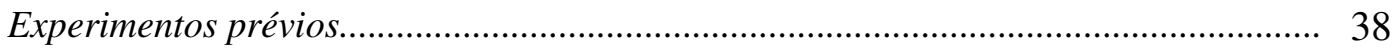

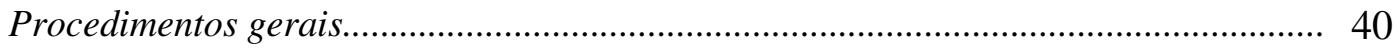

$A A$ (anteparo alto), $A B$ (anteparo baixo) e AT (anteparo baixo/anteparo transparente) 41

Teste de generalização da discriminação entre alternativas teclado visível x teclado

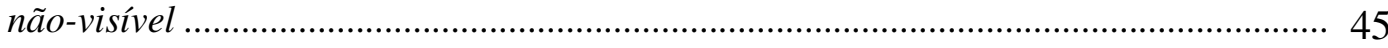

Escolha entre teclados: orientação corporal (OC) e visibilidade dos olhos (VO).......... 46

Escolha entre experimentadores: orientação corporal (OCexp) e visibilidade dos

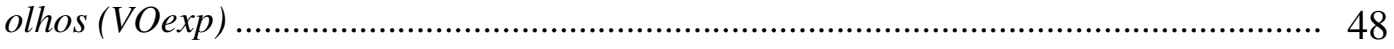

Registro dos dados e análise estatística...................................................................... 50 
RESULTADOS

Condições AA, AB, AT e fase de generalização.

Condições $O C$ e VO.

Condições OCexp e VOexp...

DISCUSSÃO.

Os olhos e a orientação corporal do experimentador na escolha de um teclado.

Os olhos e a orientação corporal na escolha de um experimentador

Anteparos e a visibilidade potencial do teclado.

APÊNDICE A: Justificativa para determinação do número de repetições para cada condição experimental.

APÊNDICE B: Descrição do método de aleatorização usado para contrabalançar as características a serem controladas nos experimentos.

APÊNDICE C: Dados coletados. 


\section{INTRODUÇÃO}

Até há pouco mais de quinze anos atrás, eram relativamente poucos os estudos sobre a cognição do cão. O interesse era centrado nos chimpanzés e bonobos, através dos quais se procurava encontrar a origem dos mecanismos cognitivos e de comunicação típicos do ser humano. Entretanto, por viver junto ao ser humano e por ter adquirido ao longo da domesticação capacidades para se comunicar como ele, o cão constitui um modelo relevante e único para a análise de processos de comunicação, especialmente no seu aspecto interespecífico (Miklósi, Topál e Csányi, 2004).

A domesticação do cão, a partir de um ancestral semelhante ao lobo atual, levou em torno de quinze mil anos, de acordo com registros arqueológicos. Durante este período, há consenso de que o cão tenha sido selecionado, em aspectos de temperamento, com a facilitação de sua convivência com o ser humano, e, em aspectos cognitivos apropriados para a realização de tarefas como a caça, o pastoreio, etc. (Hare et al., 2002; Vilá et al., 1997, Serpell, 1995, Topál et al., 2005a, Topál et al., 2005b, Topál et al. 2006a, Miklósi, 2007, Viranyi et al., 2006). Acredita-se que o cão esteja especialmente preparado para perceber e interpretar os sinais comunicativos do ser humano (Miklósi et al., 2004, Pongrácz et al. 2004, Pongrácz et al. 2001, Topál et al., 2006b), e para comunicar-se com ele usando seu repertório natural de comportamentos (Ades et al., 2000).

Hare et al. (2002) testaram três hipóteses a respeito da natureza da capacidade canina de se comunicar com o ser humano. De acordo com a primeira hipótese, ela decorreria de 
características existentes no ancestral canídeo (o lobo). Lobos são animais marcadamente sociais, e especialmente flexíveis em seu comportamento de interação, na caça coletiva e na resolução de disputas pela dominância. Lobos (canídeos, em geral) seriam aptos a prestar atenção ao comportamento dos seus conspecíficos. Os cães teriam generalizado essa capacidade para o contexto de sua vida com os seres humanos. Prevêse, a partir desta hipótese que, lobos submetidos às mesmas condições de teste que cães, apresentariam um desempenho semelhante nas interações sociais com o ser humano.

A segunda hipótese é ontogenética: as habilidades comunicativas dos cães seriam simplesmente o produto de seu desenvolvimento num contexto humano em que, de forma mais espontânea ou proposital (por adestramento), aprendem os comportamentos que lhes são requeridos. Prevê-se, a partir dessa hipótese, que a idade dos cães e o tempo de exposição ao contexto de criação com humanos, influenciariam o desempenho de comportamentos comunicativos. É também possível prever que lobos, criados do mesmo jeito que cães, adquiririam desempenhos semelhantes no relacionamento com humanos.

De acordo com a terceira hipótese, de caráter filogenético, teria havido pressão seletiva, pelas práticas de seleção artificial (típicas com cães e geradoras das múltiplas linhagens da espécie), levando a uma prontidão para decodificar sinais humanos ou para rapidamente adquirir esta habilidade. Prevê-se, com base nessa hipótese, que os cães seriam mais habilidosos do que os lobos em se comunicar com os seres humanos, mesmo quando criados sob condições análogas e mesmo quando testados precocemente em sua ontogênese.

Hare et al. (2002) usaram, com cães e lobos, uma tarefa de discriminação entre dois recipientes: os animais tinham que localizar o recipiente dentro do qual fora escondido alimento, a partir de dicas humanas como apontar, tocar e olhar para o recipiente 
correto. Em seus experimentos comparava-se o desempenho de cães e de lobos, de cães adultos e de filhotes, de cães criados por famílias e dos criados em canis com pouco contato com seres humanos. Os resultados indicaram um melhor desempenho dos cães, na tarefa de discriminação, quando comparados com os lobos. Essa capacidade de usar dicas comunicativas humanas não dependia da idade nem do tempo de exposição ao ambiente humano. Os autores tomaram esses dados como fortes indícios de que as pressões seletivas impostas ao longo do processo de domesticação exerceram, de fato, um papel fundamental no aparecimento da habilidade dos cães de responder a sinais comunicativos dos seres humanos.

Adam Miklósi e o grupo de pesquisadores húngaros da universidade de Ötvös et al. (2003) também apóiam a hipótese da seleção por domesticação da capacidade do cão comunicar-se com o ser humano. Em tarefas nas quais a solução era especialmente difícil, ou mesmo impossível, cães (mais do que lobos) tendiam a olhar para as pessoas, o contato visual seria um dos aspectos selecionados e especialmente propício para o estabelecimento da comunicação cão-ser humano.

Kubinyi et al. (2007) também acreditam que a diferença entre os cães e lobos tenha uma base genética, não sendo o simples produto do contato com o ser humano e da aprendizagem que este contato propicia. Não negam a influência do treinamento e mostraram, em seus experimentos, que lobos intensivamente socializados desde os quatro dias de idade alcançavam o mesmo nível de desempenho de cães em tarefas de escolha nas quais sinais humanos tinham de ser discriminados. Entretanto, somente alcançavam este nível a partir de dois anos de idade. Os cães se mostram proficientes, na mesma tarefa, já aos dois meses de idade. A prontidão para aprender parece então um dos elementos favorecidos pela domesticação. 
O processo pelo qual os cães adquiriram habilidades de se comunicar com o ser humano e o papel da domesticação nesse processo é ainda sujeito a controvérsia. No estudo recente de Riedel et al. (2008) com a mesma tarefa de discriminação entre dois recipientes, foram testados quatro grupos de animais de 6, 8, 16 e 24 semanas de vida. Os 64 cães, 16 em cada grupo, foram submetidos a três condições experimentais, com uma dica diferente em cada uma: (1) o experimentador apontava o recipiente correto uma vez e alternava olhares entre o cão e o recipiente correto quatro vezes; (2) o experimentador apontava quatro vezes o copo correto alternando olhares, e, (3) o experimentador colocava um marcador no copo correto (um pedaço de madeira preta e branca). Os cães foram submetidos também a uma condição de controle, sem dicas, durante a qual o experimentador mantinha seu olhar à frente.

Mesmo quando muito jovens, com seis semanas de idade, e ainda sem ter completado o período de socialização, nas três condições experimentais os cães escolheram o recipiente correto numa porcentagem superior ao acaso. Os autores tomam o resultado como um forte argumento de que os cães não adquirem a habilidade de interpretar gestos humanos através de sua experiência ontogenética, mas sim que nascem com essa habilidade. A hipótese dos efeitos seletivos da domesticação ganha reforço com esta interpretação.

Wynne et al. (2008), comentando de imediato o artigo de Riedel et al. (2008), mostraram, através de uma reanálise dos dados originais, que os resultados da condição controle teriam mascarado o efeito da idade sobre o desempenho. Excluindo-se a condição de controle, verifica-se, segundo Wynne et al. (2008), uma melhora significativa do desempenho com a idade. Isto mostra que efeitos de experiência estão envolvidos e indica um importante papel dos fatores ontogenéticos. 
Udell et al. (2008), dando prosseguimento à controvérsia, publicaram um novo estudo em que cães e lobos eram novamente comparados, diante da tarefa de escolha, sendo “apontar" a dica oferecida. Eram cinco grupos: (1) lobos, socializados desde dez dias de vida, testados em ambiente externo com uma pessoa familiar, (2) cães testados em uma sala dentro de suas casas com uma pessoa familiar, (3) cães testados em ambiente externo com uma pessoa familiar, (4) cães testados em ambiente externo com uma pessoa não familiar, e, (5) cães de abrigo testados em ambiente interno com uma pessoa não familiar. Os resultados desse estudo diferem dos anteriormente publicados. Tanto os lobos, como os cães testados em ambientes internos, apresentaram um desempenho significativo na tarefa de escolha. Contrariamente ao esperado, cães testados em ambientes externos ou cães de abrigo não foram capazes de utilizar as dicas fornecidas pelos experimentadores.

Os autores alegam que os estudos anteriores testavam os cães e lobos em ambientes diferentes (interno e externo, respectivamente) e que a diferença nas condições de teste pode ter viciado os resultados em favor dos cães. Os autores concluem que mesmo os animais geneticamente programados para responder às dicas sociais podem apresentar uma variação na habilidade devido à experiência individual, e, que, não é razoável tratar a cognição social como uma faculdade presente ou ausente, mas sim admitir que a experiência e o ambiente também influenciam o comportamento dos cães.

A discussão está em aberto, entretanto, na nossa percepção, os dados atualmente disponíveis favorecem a hipótese da domesticação, não de forma exclusiva, mas dentro de uma dinâmica de interação entre a programação genética e os efeitos moduladores do ambiente. A discussão chama a atenção para a complexidade do fenômeno da comunicação cão-ser humano e para a necessidade de serem exploradas, experimentalmente, todos os seus aspectos. 


\section{O reconhecimento de sinais espaciais}

Os experimentos até agora realizados confirmam a hipótese de que cães sejam capazes de orientar-se espacialmente usando dicas fornecidas pelo ser humano. Os sinais comunicativos espaciais dos seres humanos considerados na maioria dos estudos referem-se ao comportamento de apontar, estendendo os braços em direção ao alvo, ou direcionar o corpo para o alvo.

Hare et al. (2002) e Riedel at al (2008), como já mencionado, mostraram que cães são capazes de compreender o gesto de apontar dos seres humanos. Muitos outros estudos levam a conclusões semelhantes (Hare et al., 1998, Hare and Tomasello, 2005, Miklósi et al., 2006, Soproni et al., 2002, Gácsi et al., 2007).

Miklósi et al. (1998) submeteram cães à tarefa de escolha entre recipientes, usando como dicas apontar, acenar com a cabeça, direcionar a cabeça e inclinar o corpo. $\mathrm{O}$ desempenho individual dos cães foi investigado comparando-se a primeira metade dos ensaios com a segunda metade para cada dica comunicativa. Os resultados indicaram a presença de compreensão prévia dos cães a respeito dos gestos de apontar, acenar a cabeça e inclinar o corpo, por outro lado, a dica mais sutil de direcionar a cabeça foi aprendida pela maioria dos cães durante o experimento.

Cães parecem ser capazes de diferenciar a comunicação intencional da comunicação não intencional (Kaminski, 2008). Foram dadas aos cães, na mesma tarefa de escolha do recipiente com alimento, dicas intencionais (como apontar para o recipiente correto) ou não intencionais (como apontar para o recipiente ao olhar o relógio de pulso). Os 
animais escolheram o recipiente correto acima do acaso quando o sinal fornecido era intencional e aleatoriamente quando a dica era não intencional.

\section{Sinais de atenção}

Para que haja comunicação visual, é essencial, para o transmissor humano, que o receptor da mensagem esteja numa posição que indique estar atento e capaz de percebêlo. Um sinal visual não será captado e não terá a conseqüência desejada se, por exemplo, o indivíduo que deveria recebê-lo estiver de costas ou com o olhar distante. $\mathrm{Na}$ interação humana, é comum, no caso de inatenção, que o transmissor "chame a atenção" da outra pessoa para que o olhar desta indique que poderá ver o sinal. Sinais de atenção, na linguagem que usaremos na presente dissertação, são requeridos para aumentar a probabilidade de que uma comunicação visual tenha efeito.

Em que medida os cães são sensíveis a sinais da atenção humana, quando se trata de comunicar desejos ou intenções? As principais informações sobre o foco de atenção visual nos seres humanos estão relacionadas à orientação do corpo, da cabeça ou dos olhos. Nos estudos que investigam se cães são capazes de reconhecer sinais de atenção humana, os sujeitos experimentais são, por isso, expostos a pessoas que estão de frente ou de costas, que têm os olhos visíveis ou cobertos por uma venda.

Num primeiro experimento, Gácsi et al. (2004) submeteram cães a diferentes sinais de atenção do ser humano: o experimentador podia estar de frente ou de costas ou podia estar com os olhos cobertos por uma venda ou não, em uma situação em que um objeto era arremessado e deveria ser buscado pelo animal. Os cães pareciam levar em conta o olhar humano e sua relação com o estado de atenção, mas respondiam de maneira mais 
consistente à orientação corporal, uma diferença de resultado também evidenciada em estudos similares com chimpanzés (Povinelli \& Eddy, 1996; Kaminski, Call \& Tomasello, 2004).

Num segundo experimento (Gácsi et al., 2004), dezenove cães foram testados em duas condições em que poderiam escolher entre duas pessoas para pedir comida. Na primeira condição, duas pessoas familiares estavam sentadas em cadeiras, na direção do cão, uma delas com uma venda cobrindo os olhos, a outra sem venda. Os cães foram submetidos a doze práticas, e, ambas as pessoas sentavam-se em cada cadeira por seis práticas (em três práticas com a venda cobrindo os olhos e nas outras três com a venda na testa). As posições e condições dos olhos foram definidas aleatoriamente, a pessoa que estava sem a venda nos olhos deveria buscar o contato visual com o cão. Na segunda condição, duas pessoas não familiares estavam sentadas em lados opostos de uma mesa segurando um sanduíche na mão, uma com a cabeça orientada para o cão e outra com a cabeça orientada para o lado oposto. Cada cão foi submetido a quatro práticas de escolha. As pessoas sentavam-se duas vezes em cada lado, uma olhando para o cão e buscando o contato visual e outra olhando para o lado oposto. As posições e orientações da cabeça foram definidas aleatoriamente. Os cães eram sempre recompensados na primeira situação, e nunca na segunda. Em ambas as condições, a proporção de escolha da pessoa que exibia sinais de atenção (de frente ou sem a venda nos olhos) superou o acaso. Entretanto, os cães se dirigiram mais para a pessoa que estava de frente (na segunda condição) do que para a pessoa sem a venda (na primeira condição).

Para verificar se cães seguiriam o olhar do ser humano em uma situação que não envolve comida, Agnetta et al. (2000) submeteram dez cães a uma situação em que o experimentador virava sua cabeça olhando em três direções (para cima, à esquerda e à direita) por cinco segundos. Na condição de controle o experimentador olhava para o 
cão por cinco segundos. Cada cão foi submetido a dezoito práticas, seis com o experimentador olhando para cima, seis olhando para frente, três à direita e três à esquerda. Nenhum dos cães seguiu a direção do olhar humano para o espaço vazio, sugerindo que cães não se interessam pelo que os seres humanos estão olhando fora do contexto de dicas de alimentação. Segundo os autores, o resultado talvez se explique pelo fato de cães estarem mais acostumados a usar sinais sonoros de comunicação: o simples olhar, sem dica sonora, não surtiria por isso efeito.

Com condições semelhantes às usadas por Povinelli el al. (1999) com chimpanzés e crianças, Soproni et al. (2001) proporcionaram a cães, na tarefa de escolha do recipiente, sinais como: o experimentador permanecia com a cabeça imóvel, alternando olhares entre o recipiente correto e o cão, tentando estabelecer contato visual nesses relances. Quatorze cães participaram desse estudo e foram submetidos à um total de oito práticas. Os cães não seguiram as dicas do olhar do ser humano.

Ao compararem os resultados na primeira e na segunda metade das práticas, os autores verificaram um efeito interessante: na primeira metade das práticas, os cães pareciam levar em conta o sinal dos olhos do ser humano, não para escolher o recipiente correto, mas, ao contrário, evitando consistentemente seguir a direção do olhar do experimentador. A esquiva do olhar humano foi atribuída ao fato de que entre os canídeos o olhar de um dominante pode representar uma ameaça ou incitar um comportamento submisso em outros cães. Essa dica, de alternar o olhar entre o recipiente correto e os cães teria sido mal-interpretada pelos cães já que o experimentador era uma pessoa não familiar.

Os resultados de Soproni et al. (2001) indicam que os cães parecem ser capazes de perceber sinais de atenção visual do ser humano, uma habilidade essencial para se estabelecer comunicação visual. Reconhecem, entretanto, com maior facilidade os sinais 
relacionados à orientação corporal, do que os relacionados ao olhar do ser humano. Miklósi (2007) nota que diante de uma pessoa com uma venda nos olhos, cães reagem geralmente com alguma hesitação, um indício de que o olhar não está sendo totalmente ignorado.

Dizer que cães têm sensibilidade a sinais de atenção do ser humano e mostrar que os usam em tarefas de discriminação ou durante outros aspectos interacionais, não significa necessariamente que eles possuam uma representação cognitiva do que seja olhar e de que tenham uma espécie de "teoria da mente" a respeito do comportamento visual das pessoas. Uma interpretação mais simples dos experimentos citados poderia ser que o cão utiliza os sinais percebidos (de postura, posição do corpo, direção do olhar) das pessoas para orientar o seu próprio comportamento.

\section{Sinais de atenção e cumprimento de uma ordem}

Cães respondem com maior frequiência e prontidão ao comando "deita" quando o seu dono está de frente do que quando está distraído, olhando ao longe, de frente para outra pessoa ou, ainda, quando existe um anteparo entre o cão e o dono (Virányi et al., 2004). Os autores comentam que uma interpretação parcimoniosa sugeriria que os cães respondem às dicas de atenção em termos de reforço e aprendizagem sobre relações estímulo-resposta. Vivendo no seio de uma família, o cão teria muitas oportunidades de aprender sobre o comportamento humano. O resultado do estudo poderia ser, assim, interpretado como decorrente da aquisição de uma resposta a um estímulo discriminativo (a visão dos olhos, da face ou da orientação corporal do ser humano). Essa suposição é suportada pelo fato dos cães terem respondido com baixa freqüência 
ao comando "deita" na condição do anteparo em que o ser humano estava fora do campo de visão do cão, e, portanto, o estímulo discriminativo estava ausente.

Segundo os autores, a explicação parcimoniosa já não seria tão apropriada ao resultado de que os cães reagem diferencialmente ao dono olhando ao longe ou conversando com outra pessoa, já que nessas situações, apesar de o estímulo discriminativo (o olhar do dono) estar no campo visual dos cães, eles também responderam menos ao comando "deita". Não nos parece que este argumento dos autores elimine de vez uma interpretação em termos de aprendizagem.

Call et al. (2003) também buscaram verificar se cães são sensíveis aos sinais de atenção do ser humano em uma situação de proibição em que os cães eram alertados para não pegar a comida do chão. Doze cães de várias raças foram submetidos a diferentes sinais de atenção do experimentador, olhos abertos, olhos fechados, de costas para a comida que estava no chão, ou ainda, distraído olhando para um jogo de computador. Cada cão recebeu oito práticas de cada condição experimental, e cada condição aconteceu somente uma vez por dia. A ordem entre as condições experimentais em cada dia foi aleatorizada. Verificou-se que os cães agiam de forma diferente quando o ser humano estava de olhos abertos ou fechados: a tendência em pegar a comida era menor quando o experimentador estava de olhos abertos do que quando estava de olhos fechados. Uma possível explicação, segundo os autores, é que os cães poderiam ter aprendido, no passado, a responder a uma dica discriminativa, por exemplo, olhos abertos, evitando “desobedecer” à ordem de não comer. Essa explicação, segundo eles, aplicar-se-ia menos ao resultado da condição em que o experimentador estava distraído, porém, com os olhos abertos, em que os cães também se comportaram como se ele não pudesse vêlos. O estudo conclui afirmando que cães, aparentemente, sabem quando o ser humano pode ou não vê-los. 
Saber quando o outro pode vê-lo, é uma habilidade que oferece muitas vantagens para animais que vivem em grupo, argumentam Brauer et al. (2004). O objetivo de seu estudo foi investigar a habilidade dos cães levarem em conta a perspectiva visual do ser humano. Dez cães foram testados numa situação em que eram proibidos pelo experimentador de se servirem de uma comida depositada no chão. Após a proibição, o experimentador sentava-se em uma cadeira e os cães podiam mover-se livremente na sala. Duas condições iniciais foram propostas: na primeira, havia um anteparo perpendicular à posição do experimentador permitindo que ele tivesse acesso visual à comida no chão, e, na segunda, o anteparo era posicionado de tal forma a bloquear o acesso visual do experimentador à comida.

O anteparo, nesse caso, tem a função de bloquear o acesso visual do ser humano ao cão, da mesma forma que nas situações em que ele se coloca de costas ou com uma venda nos olhos. Entretanto, a condição do anteparo difere das anteriores uma vez que não envolve uma dica proveniente diretamente do ser humano, e, também por caracterizar mais claramente a diferença entre poder ser visto ou não.

Neste primeiro experimento de Brauer et al. (2004), cada cão recebeu oito ensaios em cada condição, duas práticas por dia, sendo contrabalançada a ordem da apresentação das duas condições. A frequiência com que os cães pegavam ou não a comida proibida do chão foi influenciada pelo acesso visual do experimentador: os cães preferiram pegar a comida proibida com maior freqüência quando o anteparo estava bloqueando o acesso visual do experimentador para o cão do que no caso contrário.

Em um segundo experimento, procurou-se investigar se o mais importante para o cão era evitar ser visto aproximando-se da comida, ou evitar ser visto pegando a comida do chão. Foram programadas três condições: na primeira condição, utilizou-se o mesmo anteparo do primeiro experimento; na segunda, um anteparo do mesmo tamanho, mas 
com uma janela próxima ao chão que tornava a comida visível para o experimentador, embora impedisse a visão da aproximação do cão à comida, e, na terceira, um anteparo suficientemente pequeno para bloquear somente a visão da comida. Tanto na segunda quanto na terceira condição, foi menor a freqüência do comportamento de pegar a comida proibida do que na primeira condição com o anteparo grande e totalmente fechado. Esse resultado indica que os cães preferem não ser vistos pelo experimentador tanto quando estão se aproximando da comida proibida, quanto no momento em que estão pegando a comida proibida do chão.

Os estudos de Call et al. (2003) e de Brauer et al. (2004) são importantes por fornecerem evidências de que os cães são capazes de perceber quando o ser humano pode ou não vê-los, e modular o comportamento de acordo com o acesso visual do ser humano a eles.

\section{Chamar a atenção}

São poucos os estudos sobre a capacidade do cão "chamar a atenção" do dono. Em princípio, um comportamento de "chamar a atenção" somente ganha significado enquanto tal se anteceder outro comportamento comunicativo e se lhe servir de condição. No estudo de Miklósi et al. (2000), foi criada uma situação em que um alimento era escondido, diante dos cães, num de vários recipientes, observando-se o comportamento dos animais na presença do dono (que ignorava a localização exata do alimento). Os cães se comportaram de maneira que sugere que estivessem, de um lado, chamando a atenção dos donos, de outro, indicando a ele o recipiente em que estava o alimento. Apresentaram (numa freqüência maior do que em condições de controle) 
comportamentos de vocalização, alternância de olhares e idas-e-vindas entre o dono e o recipiente. Nestes comportamentos estão mesclados, de uma forma difícil de distinguir, um componente de "chamar a atenção" e um componente de direcionamento espacial. Os autores não descartam a participação de um componente operante no comportamento de mostrar, mas acreditam que esta hipótese não explica o aumento de olhares em direção ao dono (na condição em que havia alimento escondido num dos recipientes) nem a alternância de olhares dos cães entre o dono e o recipiente em que estava o alimento. Não existe, por enquanto, a nosso ver, um estudo rigoroso sobre o comportamento de "chamar a atenção" por parte de cães.

\section{Comunicação por meio de sinais arbitrários}

A comunicação entre o ser humano e indivíduos de algumas espécies de animais, incluindo o cão, pode estabelecer-se por meio de sinais arbitrários. Esses sinais arbitrários, também denominados lexigramas, tomam, por assim dizer, o lugar e a função de sinais espontâneos gerados normalmente durante uma interação costumeira entre animais e os humanos que cuidam deles. Através de treinamento e interação, pesquisadores procuraram criar situações que proporcionaram o desenvolvimento de habilidades para compreensão e produção lingüística, através de sistemas de signos arbitrários, em animais de diversas espécies, como, por exemplo, o chimpanzé (Kellogg \& Kellogg, 1933; Hayes \& Hayes, 1951; Gardner \& Gardner, 1971; Fouts \& Mellgren, 1976; Savage-Rumbaugh, McDonald, Sevcik, Hopkins \& Rubert, 1986), leão-marinho (Schusterman \& Krieger, 1984), golfinho (Herman, Richards \& Wolz, 1984), papagaio (Pepperberg, 1981, 1991, 1999) e, também, recentemente, o cão (Rossi \& Ades, 2008). 
Os sistemas de sinais arbitrários instalados no comportamento de animais, visando uma comunicação com o ser humano, podem ser constituídos de movimentos específicos: é o caso do American Sign Language instaurado pelos Gardners para se comunicar com Washoe e com outros chimpanzés. Também podem ser implementados através de uma interface física, um teclado de computador como o utilizado por Duane Rumbaugh e Savage Rumbaugh com Lana e outros chimpanzés, ou, até mesmo, um teclado sonoro com símbolos arbitrários (Rossi \& Ades, 2008). A interface de comunicação tem a vantagem de facilitar bastante o treino dos animais exigindo deles um mínimo de capacidade motora para que gerem sinais perceptíveis pelo ser humano. No caso do cão, um movimento de pressionar teclas é mais fácil de ser estabelecido do que o treinamento de movimentos diferentes para diferentes mensagens.

Um dos estudos pioneiros no desenvolvimento de uma interface de comunicação interespecífica foi realizado por Duane Rumbaugh. Uma chimpanzé, Lana, foi treinada a usar um painel computadorizado que continha dezenas de signos arbitrários. Quando Lana tocava com o dedo o painel, o som da palavra correspondente ao sinal era produzido. Ela demonstrou ter a capacidade de discriminar os lexigramas e associá-los com objetos e ações e chegou a combinar símbolos para formar sentenças mais longas.

Já entre os bonobos (Pan paniscus), primatas que usam mais gestos e vocalizações do que os chimpanzés comuns, destaca-se Kanzi, que demonstrou uma grande facilidade para se comunicar a partir de um painel com signos arbitrários (Figura 1; SavageRumbaugh \& Lewin, 1994). Quando filhote, Kanzi acompanhava sua mãe adotiva enquanto ela era treinada a usar o painel com lexigramas, e pode ter adquirido parte de sua competência inicial a partir desta exposição passiva. Vários estudos sobre produção e compreensão lingüística, ao longo dos anos, foram realizados com Kanzi. Um deles buscou avaliar em Kanzi a capacidade de entender o inglês falado ao seu redor. Os 
testes consistiram em mostrar a ele três fotografias ou três lexigramas e então dizer a palavra associada a um deles. Esse teste incluiu 35 diferentes itens usados em 180 ensaios com inglês e 180 ensaios com lexigramas. Kanzi acertou 95\% com os lexigramas e $93 \%$ com as palavras em inglês. A pesquisadora concluiu que, aparentemente, a aquisição da linguagem por símbolos foi facilitada pela habilidade para compreensão do inglês falado. Savage Rumbaugh et al. (1993) compararam o desempenho de Kanzi com uma criança de dois anos de idade, Alia, quanto à capacidade de compreensão lingüística. Dentro de uma rotina de interação social espontânea eles foram treinados a utilizar um teclado com lexigramas. A compreensão de Kanzi e Alia foi comparada diante de mensagens novas, obtidas por combinação de palavras. Constatou-se uma boa compreensão das mensagens, mesmo diante das recombinações, com uma pequena superioridade de desempenho por parte de Kanzi.

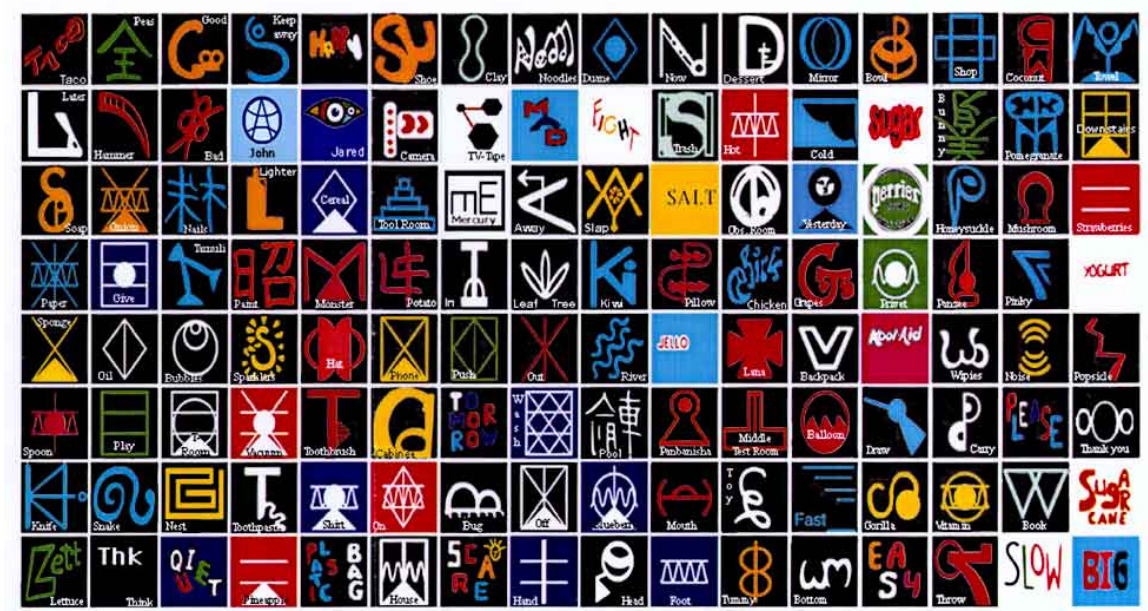

Figura 1. Painel com lexigramas (símbolos arbitrários) usado por Kanzi. 


\section{O uso de sinais arbitrários pelo cão}

Rossi \& Ades (2008), inspirando-se no tipo de procedimento de produção de sinais usado com Lana e Kanzi, treinaram uma cadela sem raça definida, chamada Sofia, a comunicar seus desejos e necessidades básicas como "água”, “comida”, “casinha”, "passear", "brinquedo", "carinho" e "xixi" por meio do toque da pata em um teclado com lexigramas. Sofia passou por várias fases de treinamento, desde o treinamento que geralmente inicia o adestramento (comandos básicos de obediência) até a aquisição da discriminação de lexigramas.

Depois das etapas de treinamento, para verificar a propriedade motivacional e interacional do uso dos lexigramas por Sofia, seu comportamento de usar o teclado foi filmado em situações naturalísticas, quantificando-se os comportamentos antecedentes e conseqüentes a este uso. Todos os objetos que poderiam ser requeridos através do uso dos lexigramas encontravam-se próximo ao animal, no mesmo ambiente, assim como o experimentador.

Os resultados mostraram claramente a pertinência do uso de lexigramas, na situação de interação natural com o experimentador. Tanto antes como depois de pressionar a tecla correspondente a um possível incentivo (água, alimento, brinquedo, etc.), Sofia exibia comportamentos dirigidos a este incentivo, uma indicação de que a pressão à tecla estava sendo usada apropriadamente para a satisfação de um desejo e visando um objetivo específico. A rotina de utilização do teclado por Sofia continuou sendo empregada dentro do contexto familiar após o término do experimento. Segundo relata sua atual proprietária, ao acordar Sofia pede "carinho", em circunstâncias em que poderia sentir sede, pede "água", vendo comida ou brinquedos, pede "comida" ou 
"brinquedo", respectivamente, e à noite, quando ela quer ser coberta com uma manta, ela pede "casinha".

Um dos aspectos do comportamento de Sofia chamou bastante a atenção dos pesquisadores: os olhares que ela dirigia ao experimentador, na situação de uso do teclado. Esses olhares ao experimentador apareciam quando Sofia estava se dirigindo ao teclado, mas eles eram especialmente marcados depois de usá-lo, quando se tornavam mais freqüentes até do que os olhares ao incentivo.

O que significam os olhares do cão numa situação de produção de sinais? Significam que o uso de uma tecla está sendo associado, pelo cão, ao comportamento que produzirá no dono, ou seja, ao atendimento do pedido feito. Quando não há resposta do experimentador, no sentido de atender ao pedido (oferecendo água, alimento, brinquedo, etc.), Sofia tecla novamente o lexigrama, até ser atendida. A resposta ao teclado parece, assim, conformar-se à definição skinneriana de "mand", ou seja, de um comportamento mantido pela conseqüência que gera em outro indivíduo.

A produção de sinais por meio do teclado por Sofia tem, portanto, características próprias de atos comunicativos: os olhares podem representar: (1) uma maneira de saber se o experimentador está iniciando o atendimento ao pedido; (2) um comportamento de chamar a atenção; ou (3) uma maneira de indicar (espacialmente) o incentivo, através de olhares alternados entre o experimentador e este incentivo. O processo de comunicação com lexigramas é "triangular", pois, envolve o cão, o teclado e o ser humano que servirá (como geralmente servem os seres humanos do ponto de vista dos cães) como cumpridor de pedidos e realizador de desejos. O teclado é um "facilitador" da comunicação entre o cão e o ser humano, permitindo que o animal substitua o comportamento natural de pedir pelo comportamento de teclar no símbolo apropriado, tornando a transmissão da informação mais clara e eficiente. 
Verificou-se também a existência de um efeito de audiência no desempenho de Sofia ao teclado. Sessões de registro filmado do comportamento de Sofia em presença do teclado, mas com o experimentador ausente, indicaram que, nesta condição, ela nunca teclava pedidos. Era claro que respostas ao teclado necessitavam, como condição, que o experimentador estivesse próximo. Mas, em que medida a atenção demonstrada pelo experimentador para Sofia e para o teclado também seria uma condição para o desempenho de Sofia?

Quando chimpanzés ou cães usam um sistema simbólico implementado pelo ser humano, cabe perguntar-se a respeito de características análogas à comunicação convencional eventualmente presente nesse processo. Na comunicação humana, existem sinais acústicos, as palavras, que tanto emissor quanto receptor devem conhecer e relacionar aos mesmos referentes. Palavras podem ser ditas de longe e podem ser entendidas mesmo que não possa ser visto o seu emissor. Mas os sinais podem também ser visuais, a própria linguagem gestual que acompanha a fala humana é visual. Os sinais visuais enviados pelo emissor modificam o comportamento do receptor, mesmo algum tempo depois de terem sido recebidos, sendo então provável a intervenção de processos de memória.

O emissor humano pode combinar de maneiras imprevisíveis sinais elementares em forma de sentenças e pode referir-se a objetos ausentes, propriedades que definem os aspectos sintáticos e semânticos da comunicação humana. Para que a comunicação se estabeleça com sucesso o emissor pode usar várias estratégias para chamar a atenção do receptor, que, por sua vez, precisa ter o aparato sensorial para reconhecer o sinal, e deve estar atento para receber a mensagem. Outra importante característica da comunicação humana é que existe diálogo, o receptor se torna emissor e vice-versa. 
Algumas dessas características podem ser encontradas na comunicação de Sofia com o ser humano por intermédio do teclado. Os lexigramas, de significado previamente definido, são sinais arbitrários que tanto Sofia quanto o ser humano discriminam e relacionam aos mesmos referentes. Podem ser utilizados para se comunicar com diversas pessoas. $\mathrm{O}$ uso do teclado modifica o comportamento do receptor humano, e é uma maneira do cão alcançar incentivos desejados. Ocorre de forma integrada com sinais mais "naturais", como latidos, posturas, etc.

Não existe evidência alguma, por enquanto, de que o uso do teclado possa servir dentro de um "diálogo" com o ser humano. Na experiência de Sofia, teclar é, por assim dizer, uma comunicação em mão única que não aceita modulação em ir-e-vir comunicativo. A situação de interação entre Sofia e o ser humano que mais se aproxima de uma emissãorecepção é quando um pedido feito no teclado é negado pelo experimentador, com palavras como "não" que inibem pedidos subseqüentes.

Quanto à combinação de sinais, tão típica da linguagem humana, convém mencionar que Sofia participou de um estudo sobre a compreensão semântica (Ramos et al., 2003) em que se pretendia verificar se ela era capaz de atender a comandos compostos de duas informações: uma informação referente a objetos tais como bola, chave, palito, garrafa e brinquedo e outra referente à ação (busca e aponta) a ser executada sobre um dos objetos. O uso de informações múltiplas em comandos é análogo ao uso de informações múltiplas em sentenças humanas. Sofia se mostrou capaz de executar, numa freqüência superior ao acaso, comandos de dois termos, objeto/ação.

Sofia, que será o foco do presente estudo, demonstra ser uma fonte interessante de informações a respeito de aspectos da comunicação cão-ser humano. Como outros animais "lingüísticos" já conhecidos (os chimpanzés Washoe e Lana, o bonobo Kanzi (Savage Rumbaugh et al., 1993, o papagaio Alex, Pepperberg, 1981, 1991, 1999, etc.), 
acreditamos que Sofia contribuirá, através de estudos a longo prazo, para apontar capacidades e limites do uso de sistemas arbitrários de comunicação.

\section{Influência dos sinais de atenção e do acesso visual humano no uso do teclado por}

\section{Sofia}

No presente estudo, pretendemos verificar se, quando se comunica por meio do teclado, Sofia leva em conta o acesso visual do ser humano aos sinais que ela produz. Toda comunicação visual depende do requisito de que o receptor seja, do ponto de vista da percepção e da atenção, capaz de receber os sinais enviados pelo emissor. A ausência de sinais de atenção e a existência de condições que perturbem a recepção desses sinais devem ter, a partir deste raciocínio, conseqüências negativas para o processo, inibindo a geração de sinais ou estimulando a procura de canais em que a probabilidade de recepção seja maior.

Embora Sofia já tenha demonstrado valorizar a importância da presença de um receptor para a sua mensagem, sem o qual ela não usa o teclado, faz-se necessário entender melhor o papel do receptor nessa interação do ponto de vista de Sofia. Como já foi mencionado anteriormente, após usar o teclado, Sofia tipicamente olha para o ser humano um indicativo de que ela percebe que influencia o comportamento dele, que é o elo imprescindível para a realização de seus desejos ou necessidades. A questão é se ela discrimina, na hora de pedir no teclado, os sinais de atenção do ser humano e se ela percebe que será atendida somente quando estiverem presentes sinais claros de atenção: em relação a ela ou em relação a ela usando o teclado. 
Para investigar a influência do olhar potencial do ser humano ao teclado planejaram-se experimentos em que Sofia deveria escolher entre dois teclados para pedir comida, sendo que somente um deles podia ser visto por um experimentador. Manipulou-se (1) a visibilidade do teclado, por intermédio de um anteparo, interposto entre teclado e experimentador; e (2) os sinais de atenção visual do experimentador (com os olhos vendados ou não, de frente ou de costas). Seria Sofia, quando utiliza o teclado, sensível ao estado de atenção do experimentador? Seria ela capaz de escolher, dentre dois teclados, o que fosse mais favorável no sentido de ser percebido pelo experimentador? Seria ainda ela capaz de escolher, dentre dois experimentadores, aquele que pudesse enxergá-la?

\section{Acesso visual do experimentador (anteparos): escolha do teclado}

Pediu-se a Sofia que escolhesse entre dois teclados idênticos para pedir alimento, um situado atrás de um anteparo (fora do campo visual do experimentador), e outro visível. Três foram as situações experimentais: (1) anteparo alto (condição AA): o anteparo impedia que o experimentador visse o teclado e também que Sofia visse $o$ experimentador quando teclasse; (2) anteparo baixo (condição $\mathrm{AB}$ ): o anteparo impedia que o experimentador visse o teclado, mas não interrompia a percepção do experimentador por parte de Sofia; (3) anteparo transparente (Condição AT): um dos teclados estava fora do campo visual do experimentador, atrás do anteparo baixo, o outro estava atrás de um anteparo de acrílico permanecendo visível. 
Sinais de atenção visual dos experimentadores (frente $\times$ costas / sem venda $\times$ com venda nos olhos): escolha do teclado

Como na série anterior de experimentos, Sofia devia escolher entre dois teclados idênticos, em duas condições: (1) orientação corporal (condição OC): um dos teclados diante de um experimentador de frente para ele, o outro diante de um experimentador de costas; (2) visibilidade dos olhos (condição VO): um dos teclados diante de um experimentador vendado, o outro diante de um experimentador sem venda nos olhos.

Sinais de atenção visual dos experimentadores (frente $\times$ costas / sem venda $\times$ com venda nos olhos): escolha do experimentador

Contrariamente aos experimentos anteriores, não se requeria de Sofia que escolhesse entre teclados idênticos (a partir do acesso visual ou dos sinais de atenção dos experimentadores), mas sim que ela escolhesse entre dois experimentadores, depois de ter feito um pedido em um único teclado. Os experimentadores, neste caso, apresentavam sinais de atenção diferentes: (1) orientação corporal (condição OCexp): um experimentador de frente para Sofia, o outro de costas; (2) visibilidade dos olhos (condição VOexp): um experimentador vendado, o outro sem venda nos olhos. 


\section{MÉTODO}

\section{Sujeito experimental, local do estudo e teclados}

O sujeito de estudo foi Sofia, uma cadela sem raça definida atualmente com 7 anos de idade. Sofia vive com sua família e é exposta naturalmente a todas as situações corriqueiras para um animal de estimação. Os experimentos com Sofia foram realizados no Laboratório de Cães do Instituto de Psicologia da Universidade de São Paulo. Esse laboratório fica ao ar livre e situa-se em um jardim interno do instituto. Tem aproximadamente $40 \mathrm{~m}^{2}$ de área total e uma cobertura de $10 \mathrm{~m}^{2}$. A área de uso dos experimentos é de $28 \mathrm{~m}^{2}$ (Figura 2).

Foram usados dois teclados, o teclado criado por Rossi \& Ades (2008, teclado original) e outro de mesmas dimensões e aparência, que foi usado durante duas semanas anteriormente aos experimentos para que houvesse habituação a ele (teclado novo). Tratam-se de teclados retangulares, com oito cavidades com teclas dispostas em duas fileiras, de 30 por 15 centímetros em um plano inclinado (Figura 3).

Quando pressionadas, as teclas do teclado original podem, se acionado o botão de som, produzir uma vocalização gravada (na voz do experimentador) da palavra relacionada ao lexigrama pressionado: “água”, “comida”, “casinha”, "passear”, “brinquedo" e "carinho". A sonorização das teclas nunca foi utilizada durante os experimentos do presente estudo. 

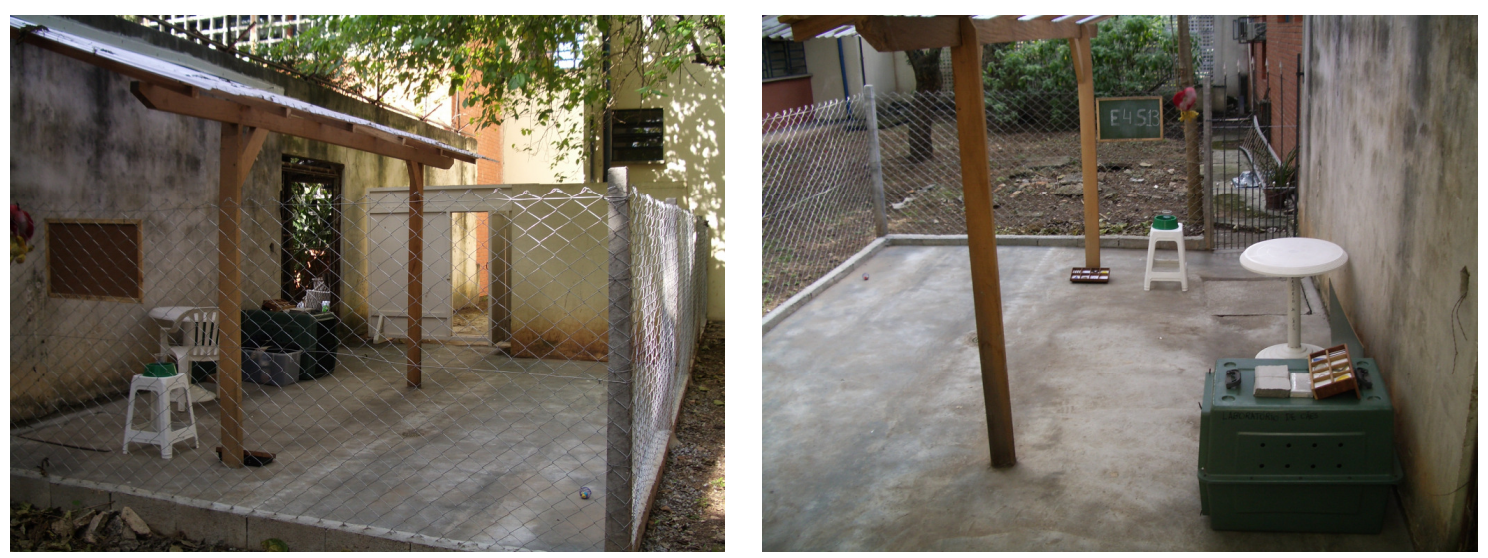

Figura 2. Laboratório de Cães do Instituto de Psicologia da Universidade de São Paulo.
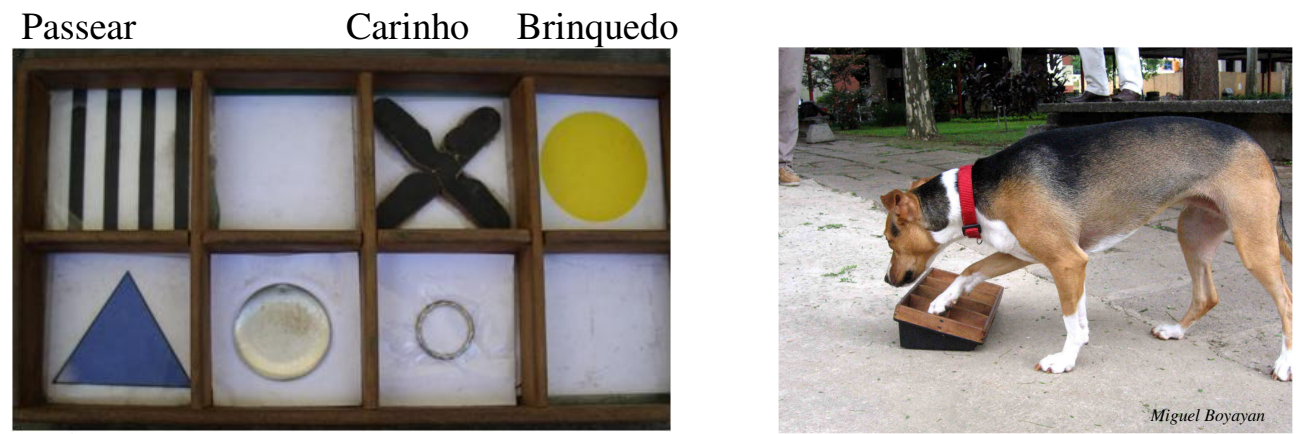

Água Comida Casinha

Figura 3. Teclado original e Sofia usando-o.

\section{Experimentos prévios}

Antes de conduzir os experimentos principais desse estudo, foram realizados experimentos sobre a influência de sinais de atenção do experimentador no comportamento de Sofia ao teclado. Os resultados desta fase, que serviu principalmente para a calibração dos procedimentos, estão descritos resumidamente abaixo. 
Experimento 1. Escolha entre dois teclados, um situado próximo ao experimentador, o outro distante.

Experimento 2. Escolha entre dois teclados, um fora do campo de visão do experimentador (atrás de um anteparo), o outro visível.

Experimento 3. Escolha entre dois teclados, um na frente do experimentador sentado, o outro atrás dele.

Experimento 4. Escolha entre dois teclados, (a) um diante de um experimentador de frente, o outro diante de um experimentador de costas; (b) um diante de um experimentador sem venda nos olhos, o outro diante de um experimentador com venda nos olhos.

Experimento 5. Escolha entre dois experimentadores, depois de efetuar um pedido ao teclado, (a) um deles de frente, outro de costas; (b) um sem venda nos olhos, o outro com venda nos olhos.

Foram 16 práticas para cada um dos experimentos prévios e a cada sessão os cinco experimentos aconteceram em ordem aleatória. Para essa fase, usou-se um esquema de reforço intermitente, reforçando uma resposta na condição favorável de atenção humana a cada três, para diminuir os efeitos de treino sobre as escolhas de Sofia.

Os resultados dos experimentos prévios, embora não tenham sido submetidos à análise estatística (apenas a uma análise dos registros filmados), não indicaram uma tendência de Sofia escolher sistematicamente as alternativas em que seria mais provável a presença de atenção humana. Ainda assim, no Experimento 2 (anteparo), Sofia optou pelo teclado visível ao experimentador em $66,7 \%$ das sessões, indicando uma possível preferência, mesmo com taxa baixa de reforço. No Experimento 5, Sofia apresentou 
uma tendência para escolher o experimentador de frente e sem a venda, para receber o alimento que pedira no teclado.

\section{Procedimentos gerais}

Para todas as condições experimentais controladas (AA, AB, AT, OC, VO, OCexp+VOexp) foram conduzidas 16 sessões em dias diferentes (somente em 3 ocasiões foram rodadas duas sessões no mesmo dia). As condições experimentais AA, AB, OC, VO, OCexp+VOexp (8 sessões na condição OCexp e 8 sessões na condição VOexp) ocorreram simultaneamente, em ordem aleatória. A condição AT foi testada somente após finalizados os primeiros experimentos. A justificativa para a escolha do número de repetições de cada condição experimental (16 repetições) está apresentada no Anexo A.

A ordem em que as condições experimentais aconteceram para cada sessão (Tabela 1) foi previamente determinada utilizando-se um procedimento de aleatorização em blocos descrito no Anexo B.

Sofia sempre foi recompensada pelas escolhas corretas (com acesso visual ou sinais de atenção do experimentador) em todas as condições experimentais, para manter alta sua motivação. A taxa intermitente de reforço nos experimentos prévios era acompanhada de baixo desempenho e interesse nas práticas experimentais.

É importante ressaltar que em nenhuma das condições o experimentador olhava para o teclado, uma vez que a intenção do estudo não era induzir Sofia a uma escolha, embora ainda não esteja claro que o olhar, de fato, induza a escolha dos cães. 
Tabela 1. Ordem em que as cinco condições experimentais ocorreram em cada sessão.

\begin{tabular}{|cc|}
\hline Sessão & Condição \\
\hline 1 & AA \\
& VO \\
& AB \\
& OC \\
& OCexp+VOexp \\
\hline 2 & OC \\
& OCexp+VOexp \\
& VO \\
& AB \\
& AA \\
\hline 3 & AB \\
& AA \\
& OCexp+VOexp \\
& VO \\
& OC \\
\hline 4 & VO \\
& OC \\
& AA \\
& AB \\
& OCexp+VOexp \\
\hline
\end{tabular}

\begin{tabular}{|cc|}
\hline Sessão & Condição \\
\hline 5 & $\mathrm{AB}$ \\
& $\mathrm{AA}$ \\
& OC \\
& $\mathrm{VO}$ \\
& OCexp+VOexp \\
\hline 6 & $\mathrm{AB}$ \\
& OCexp+VOexp \\
& OC \\
& VO \\
& $\mathrm{AA}$ \\
\hline 7 & $\mathrm{AA}$ \\
& OCexp+VOexp \\
& OC \\
& VO \\
& AB \\
\hline 8 & VO \\
& AA \\
& OCexp+VOexp \\
& AB \\
& OC \\
\hline
\end{tabular}

\begin{tabular}{|cc|}
\hline Sessão & Condição \\
\hline 9 & OC \\
& AB \\
& AA \\
& OCexp+VOexp \\
& VO \\
\hline 10 & OCexp+VOexp \\
& OC \\
& AB \\
& AA \\
& VO \\
\hline 11 & AA \\
& VO \\
& AB \\
& OCexp+VOexp \\
& OC \\
\hline 12 & OC \\
& AB \\
& AA \\
& VO \\
& OCexp+VOexp \\
\hline
\end{tabular}

\begin{tabular}{|cc|}
\hline Sessão & Condição \\
\hline 13 & $\mathrm{AB}$ \\
& $\mathrm{AA}$ \\
& OCexp+VOexp \\
& VO \\
& OC \\
\hline 14 & $\mathrm{AB}$ \\
& VO \\
& $\mathrm{AA}$ \\
& OCexp+VOexp \\
& OC \\
\hline 15 & AA \\
& OC \\
& AB \\
& OCexp+VOexp \\
& VO \\
\hline 16 & AA \\
& OCexp+VOexp \\
& VO \\
& OC \\
& AB \\
\hline
\end{tabular}

AA (anteparo alto), AB (anteparo baixo) e AT (anteparo baixo/anteparo transparente)

$\mathrm{Na}$ condição AA (Figura 4) utilizou-se um anteparo alto (1 $\mathrm{m}$ de altura e $60 \mathrm{~cm}$ de largura); na condição AB (Figura 5), um anteparo baixo $(40 \mathrm{~cm}$ de altura e $60 \mathrm{~cm}$ de largura) que permitia a Sofia olhar para o experimentador enquanto usava o teclado.

Em cada condição experimental as posições do anteparo (esquerda/direita) e dos teclados original e novo (esquerda/direita) foram contrabalançadas ao longo das 16 sessões. Uma mesa era posicionada no centro da sala, eqüidistante dos dois teclados, funcionando como um obstáculo para que Sofia não fosse diretamente para o experimentador antes de usar um dos teclados. 


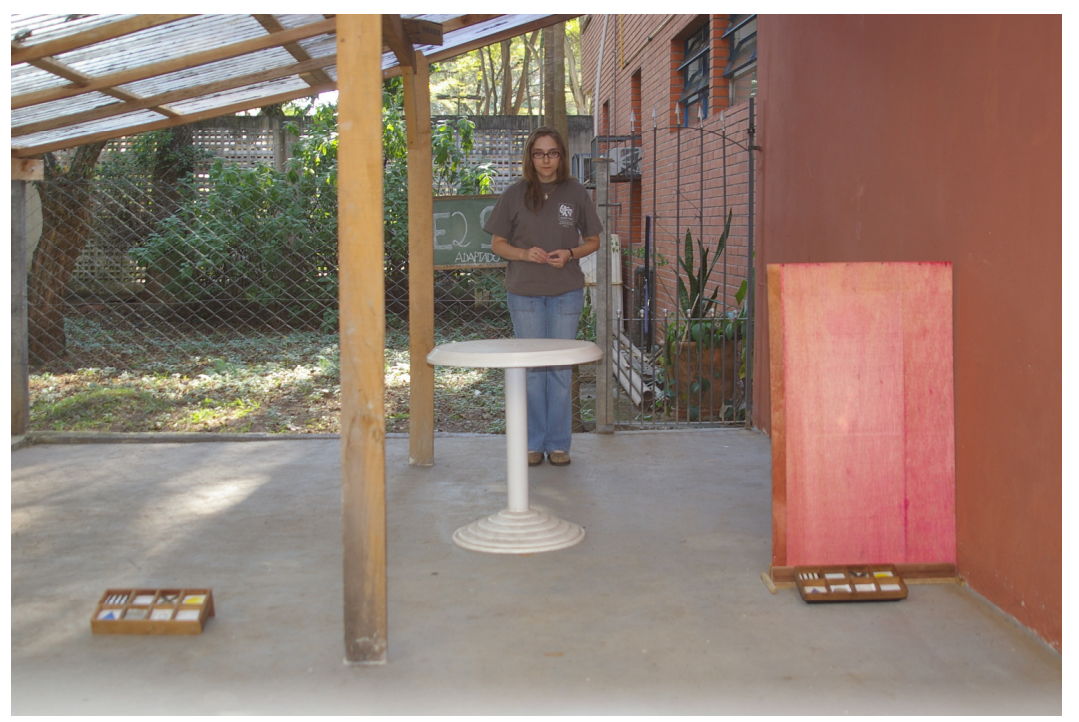

Figura 4. Condição AA: exemplo de disposição dos teclados, do anteparo e posição do experimentador.

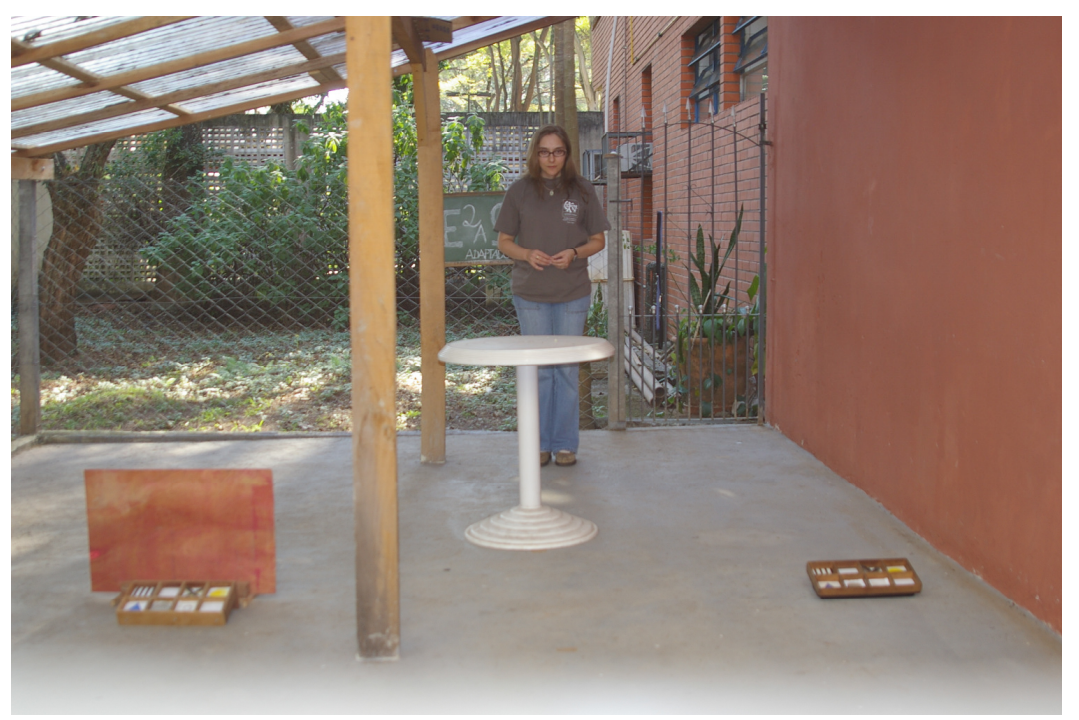

Figura 5. Condição $\mathrm{AB}$ : exemplo de disposição dos teclados, do anteparo e posição do experimentador.

A previsão, no caso de AA, a partir da hipótese de que as escolhas do animal dependem de sua percepção dos sinais de atenção do experimentador, era de que Sofia escolheria 
significativamente o teclado visível. Mas, se isso ocorresse, poder-se-ia argumentar que a escolha teria sido influenciada pelo fato de que Sofia perderia eventualmente o seu contato visual com o experimentador se usasse o teclado situado atrás do anteparo alto. Foi para eliminar esta possível interpretação que se pensou em incluir práticas na condição $\mathrm{AB}$, com um anteparo baixo que não impediria o contato visual de Sofia com o experimentador. Se a hipótese de que somente o "contato visual com o experimentador" bastaria, as escolhas de Sofia deveriam distribuir-se aleatoriamente entre ambos os teclados (com e sem anteparo) na condição AB.

Mesmo que Sofia escolhesse significativamente a alternativa do teclado visível em AA e em AB, poder-se-ia ainda argumentar que o fator em jogo fosse a esquiva de usar um teclado próximo a um anteparo e não a escolha da alternativa em que o teclado fosse visível para o experimentador. Foi para controlar um eventual fator "esquiva de anteparo" que se programou a condição AT (Figura 6), na qual, para ambas as alternativas, havia algum anteparo, um opaco de um lado e um transparente do outro lado, ambos com $40 \mathrm{~cm}$ de altura e $60 \mathrm{~cm}$ de largura. $\mathrm{O}$ anteparo transparente era dotado de uma borda branca no seu contorno, para tornar perceptível a sua presença. Se Sofia, de fato, estivesse se esquivando de usar um teclado próximo a um anteparo, ela deveria, na condição AT, recusar-se a usar qualquer um dos dois teclados, ou, até mesmo, distribuir aleatoriamente as suas escolhas. Se, ao contrário, ela levasse em conta a visibilidade do teclado para o ser humano, ela deveria dirigir-se preferencialmente para o teclado atrás do anteparo transparente.

As posições dos anteparos (direita/esquerda) e dos teclados (direita/esquerda) na condição AT também foram contrabalançadas ao longo de 16 sessões. A mesa continuou no cenário eqüidistante dos dois teclados. 


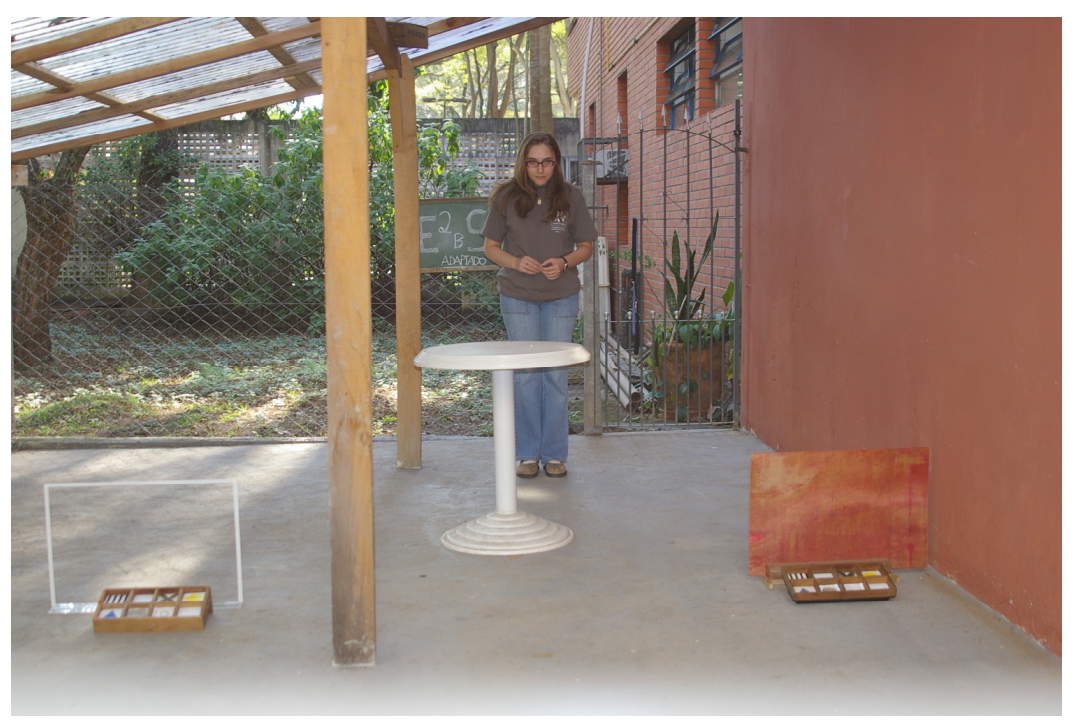

Figura 6. Condição AT: exemplo de disposição dos teclados, dos anteparos transparente e opaco, e posição do experimentador.

Em todas as três condições experimentais (AA, AB e AT), cada sessão iniciava-se com os teclados e anteparos nas posições previamente determinada pela lista de aleatorização, cuja descrição está apresentada no Anexo B. Os passos seguintes para cada sessão foram:

(1) Sofia, na porta do laboratório, recebia um pedaço de comida do experimentador.

(2) Em seguida, o experimentador emitia o comando "fica" e deslocava-se para uma posição eqüidistante dos dois teclados (um deles dentro do seu campo de visão e outro escondido atrás do anteparo);

(3) O experimentador, mantendo sempre contato visual com Sofia, a encorajava verbalmente a utilizar o teclado para ganhar mais comida;

(4) Liberada do comando "fica", Sofia podia, então, sair da posição inicial para fazer a sua escolha. 
(5) A sessão terminava quando Sofia fazia uma escolha ou após 1 minuto sem escolha.

Teste de generalização da discriminação entre alternativas teclado visível $\times$ teclado não-visível

Para verificar se a eventual preferência de Sofia pela alternativa visível do teclado não seria restrita à situação experimental, foram efetuados testes diversos, depois de realizadas as sessões da condição AT, em que era variado o tipo de obstáculo para a visibilidade e o contexto das práticas. Os testes realizados estão arrolados na Tabela 2.

Tabela 2. Descrição das modificações feitas no cenário das condições com anteparo para avaliar a capacidade de generalização de Sofia.

\begin{tabular}{cl}
\hline Sessão & Cenário experimental \\
\hline 1 & Cenário sem a mesa no centro da sala \\
2 & Substituição do anteparo por uma caixa com mochilas \\
3 & Substituição do experimentador por um auxiliar A1 \\
4 & Mudança de sala com o cenário invertido \\
5 & Substituição do anteparo por um banquinho coberto com um saco plástico opaco \\
6 & Substituição do experimentador por um auxiliar A2 \\
7 & Substituição do anteparo por uma cadeira coberta com um pano \\
8 & Substituição do anteparo por outro anteparo do mesmo tamanho de papelão \\
9 & Anteparo caixa com mochilas versus anteparo transparente \\
10 & Anteparo banquinho coberto com um saco plástico opaco versus anteparo transparente \\
11 & Um jardim em que uma árvore foi usada como anteparo para esconder um dos teclados \\
\hline
\end{tabular}

Em todas as sessões da etapa de generalização utilizou-se o mesmo procedimento das condições AA, AB e AT. Procurou-se variar as posições dos teclados e anteparo, assim como nos experimentos controlados. 
Escolha entre teclados: orientação corporal (OC) e visibilidade dos olhos (VO)

Sofia podia escolher um dentre dois teclados, um situado diante de uma pessoa de frente e outro diante de uma pessoa de costas (condição OC - Figura 7a), ou, entre um teclado situado diante de uma pessoa com venda nos olhos e outro diante de uma pessoa sem venda nos olhos (com a venda na testa) (condição VO, Figura 7b). As posições dos teclados original e novo (direita/esquerda), dos dois experimentadores E1 e E2 (direita/esquerda), assim como a condição de cada experimentador (frente e costas para a condição OC, ou, com ou sem venda para a condição VO) foram contrabalançadas ao longo das 16 sessões.

Cada sessão iniciava-se com os dois experimentadores sentados, eqüidistantes da porta, cada um de um lado da sala na posição e condição visual previamente determinadas por uma lista de aleatorização. Um pedaço de comida era colocado em um pote no meio da sala antes de iniciar a sessão. Os passos seguintes foram como descritos abaixo:

(1) Um auxiliar abria a porta da sala segurando Sofia na guia por 5 segundos para que ela pudesse observar o cenário.

(2) Sofia então era solta para primeiro comer a comida que estava no chão no meio do caminho, e, em seguida, pedir mais comida em um dos dois teclados.

(3) A sessão terminava quando Sofia fazia uma escolha ou após 1 minuto sem escolha.

O experimentador que se posicionava de frente ou que estava sem a venda nos olhos buscava sempre o contato visual com Sofia. 

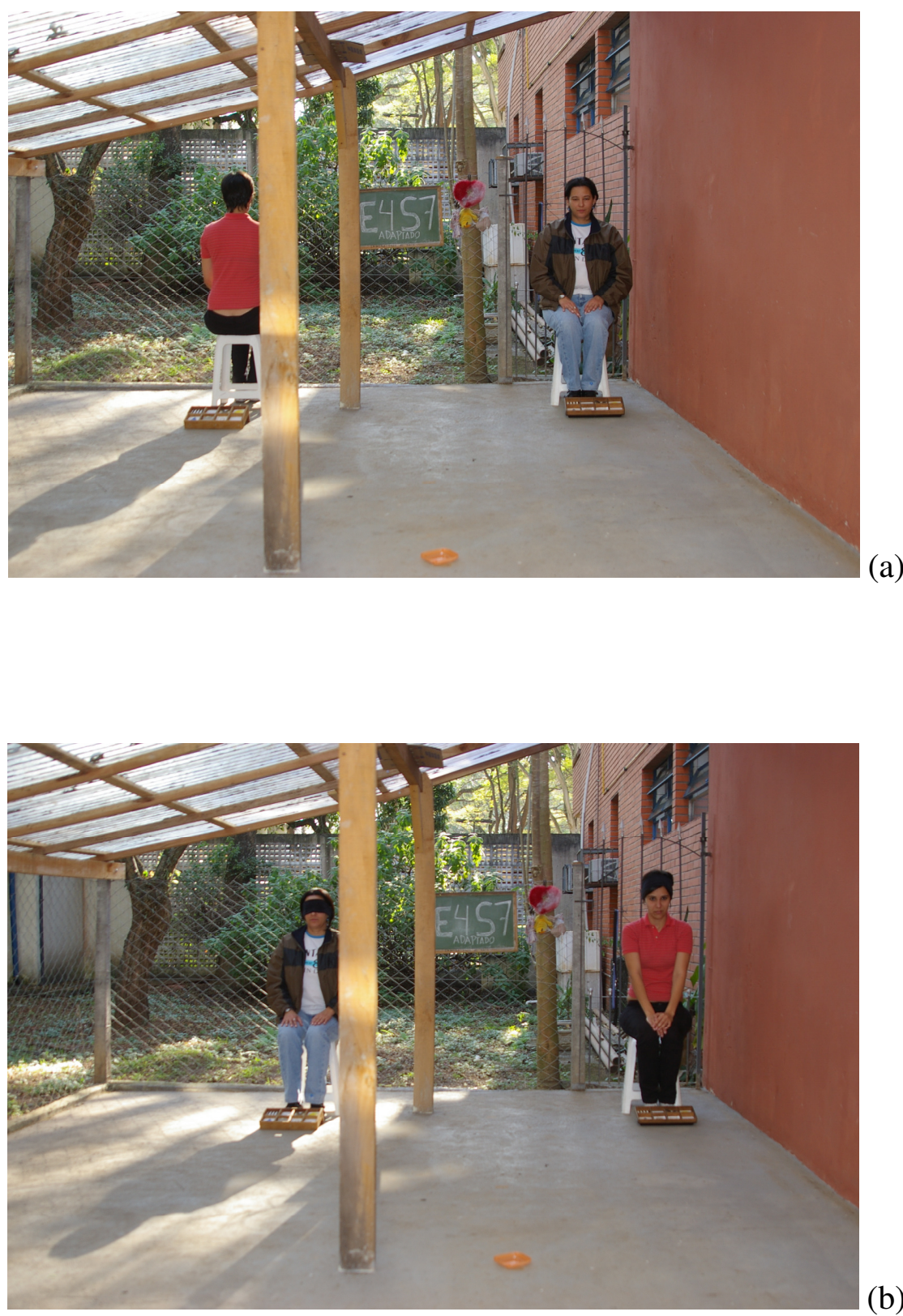

Figura 7. Fotos que exemplificam a disposição dos teclados e dos experimentadores nas condições experimentais: (a) OC - relacionada à orientação corporal; (b) VO - relacionada à visibilidade dos olhos. 


\section{Escolha entre experimentadores: orientação corporal (OCexp) e visibilidade dos olhos (VOexp)}

As 16 sessões programadas para as condições OCexp+VOexp foram divididas entre as duas condições, ou seja, para metade delas um dos experimentadores esperava Sofia de frente e o outro de costas, e na outra metade um dos experimentadores esperava Sofia com venda nos olhos e o outro sem venda nos olhos (com a venda na testa). A posição dos experimentadores E1 e E2 (direita/esquerda), assim como a condição de cada experimentador (frente ou costas, com ou sem venda) foram contrabalançadas ao longo das 16 sessões, de tal forma que cada experimentador posicionou-se 8 vezes de cada lado ( 2 vezes de frente, 2 vezes de costas, 2 vezes com a venda nos olhos e 2 vezes sem venda nos olhos).

Nas condições OCexp+VOexp foram aproveitados os dados coletados no experimento prévio (Experimento 5) que tinha um procedimento idêntico, perfazendo, assim, um total de 16 repetições para cada condição, OCexp e VOexp.

(1) Os dois experimentadores lado a lado ofereciam pedaços de comida a Sofia (Figura 8a).

(2) Após 5 segundos, ambos paravam de dar comida e permaneciam em silêncio olhando para frente (Figura 8b).

(3) Sofia pedia mais comida no único teclado que estava na sala eqüidistante dos dois experimentadores, enquanto cada um deles dava um passo, afastando-se lateralmente do outro (ficando a uma distância aproximada de $1 \mathrm{~m}$ um do outro) e assumindo a posição ou condição previamente determinadas na lista de aleatorização (Figura 9a/b). 
(4) A sessão terminava quando Sofia escolhia um dos experimentadores, ou após 1 minuto sem escolha.

Durante toda a sessão o experimentador que estava de frente ou sem a venda nos olhos buscava o contato visual com Sofia.
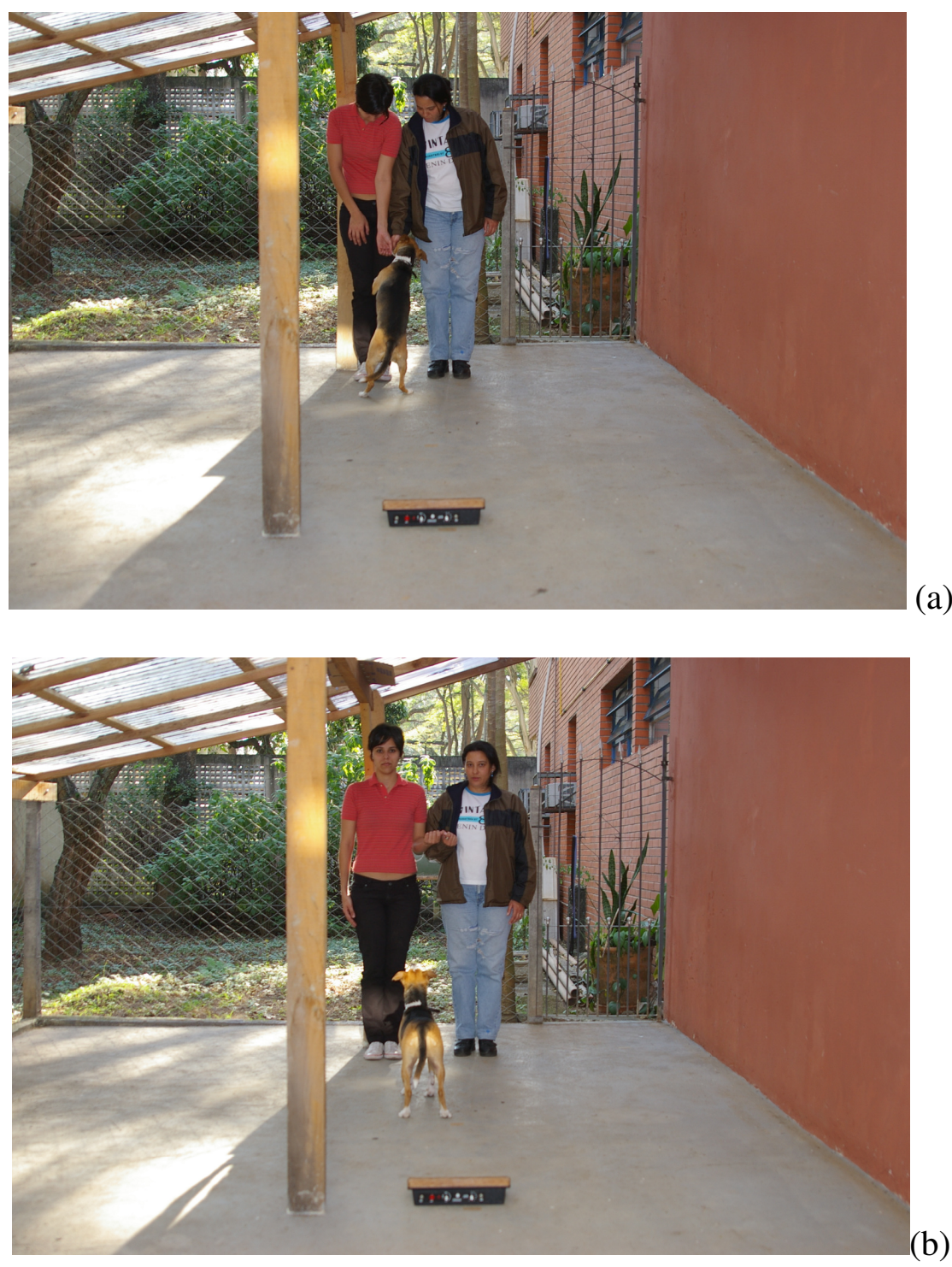

Figura 8. Condições experimentais OCexp+VOexp. (a) ambos o experimentadores alimentam Sofia; (b) postura no final da alimentação. 

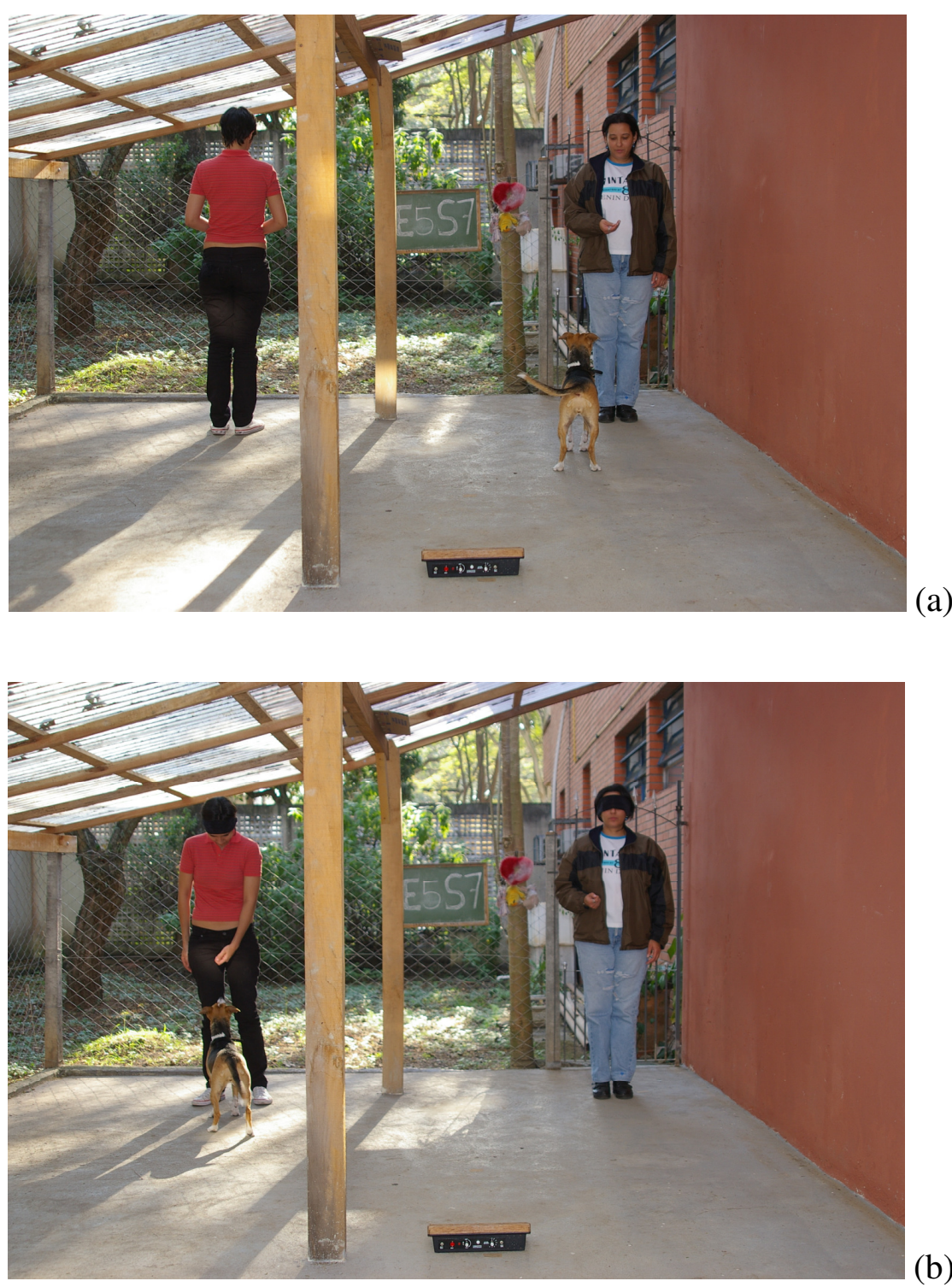

Figura 9. Fotos que exemplificam a disposição do teclado e dos experimentadores durante a escolha de Sofia. (a) condição OCexp; (b) condição VOexp.

\section{Registro dos dados e análise estatística}

Além das informações gerais como data e nomes dos experimentadores e auxiliares, todas as sessões foram filmadas com a câmera Panasonic SDR-H200 e analisadas posteriormente quantitativamente quanto à escolha de Sofia e qualitativamente. 
Em cada experimento, para comparar a escolha de Sofia com uma escolha compatível com o acaso utilizou-se o teste Binomial, com a suposição de que a distância temporal entre as sessões do mesmo experimento era suficientemente grande para eliminar a influência da escolha de uma sessão na outra. Para avaliar se a escolha de Sofia foi influenciada por outros fatores como lado da sala (direita/esquerda) e teclado (original/novo) utilizou-se uma aproximação da Binomial pela distribuição Normal. O nível de significância adotado para cada teste foi de 5\%. 


\section{RESULTADOS}

Somente em duas das 112 sessões planejadas para a fase de testes (16 sessões para cada condição experimental, AA, AB, AT, OC, VO, OCexp e VOexp) Sofia deixou de efetivar uma escolha, ambas na condição AA. Na fase de generalização ela sempre fez alguma escolha.

Buscou-se avaliar se a escolha de Sofia sofreu influência do lado (esquerdo/direito) da sala, considerando todas as condições experimentais agrupadas. Observou-se que Sofia escolheu o lado esquerdo em 42,7\% (das 110 sessões consideradas), não sendo, portanto, uma escolha viciada pelo lado da sala $(\mathrm{p}=0,127)$. Procurou-se também avaliar se as escolhas de Sofia sofreram influência de eventuais diferenças entre o teclado original e o teclado novo. Constatou-se que, de todas as sessões em que ela escolheu um dos teclados (78 sessões ao todo, não sendo consideradas as sessões das condições VOexp e OCexp em que havia somente um teclado), Sofia escolheu o teclado original em $43,6 \%$ das vezes $(\mathrm{p}=0,258)$. Portanto, a escolha de Sofia não foi influenciada por um lado específico da sala nem tampouco por um dos teclados.

Nas condições OC, VO, OCexp e VOexp, em que ela deveria escolher entre dois experimentadores, não foi feito teste para verificar se a escolha sofreu influência de preferência por uma pessoa em particular, pois não foram sempre as mesmas duas pessoas que assumiam as posições de experimentadores. 


\section{Condições $A A, A B, A T$ e fase de generalização}

A Figura 10 mostra a distribuição da escolha de Sofia nas condições AA, AB e AT, o número de práticas considerado para os cálculos, assim como os resultados dos testes estatísticos que compararam a distribuição da escolha observada com uma escolha compatível com o acaso (50\%). Tanto na condição AA quanto na condição AB, Sofia escolheu consistentemente o teclado potencialmente visível para o experimentador ( $\mathrm{p}=0,002$ e $\mathrm{p}<0,001$, respectivamente), indicando que não é somente o contato visual com o experimentador que influencia a sua escolha. Na condição AT, como Sofia escolheu o anteparo transparente $87,5 \%$ das sessões $(\mathrm{p}=0,004)$, pode-se concluir que a sua escolha nas condições $\mathrm{AA}$ e $\mathrm{AB}$ também não se deve a um efeito de esquiva a anteparo.

A Figura 11 exemplifica a direção do olhar de Sofia e do experimentador ao longo de uma sessão na condição experimental AT. Essa seqüência mostra que no início, antes de fazer a escolha entre um dos teclados, Sofia busca o contato visual com o experimentador que mantém seu olhar fixo nela. Esse contato visual direto inicial além de evitar dar dicas sobre qual teclado Sofia deveria escolher também incitava o início de um processo de comunicação, motivando Sofia a pedir comida em um dos teclados. 


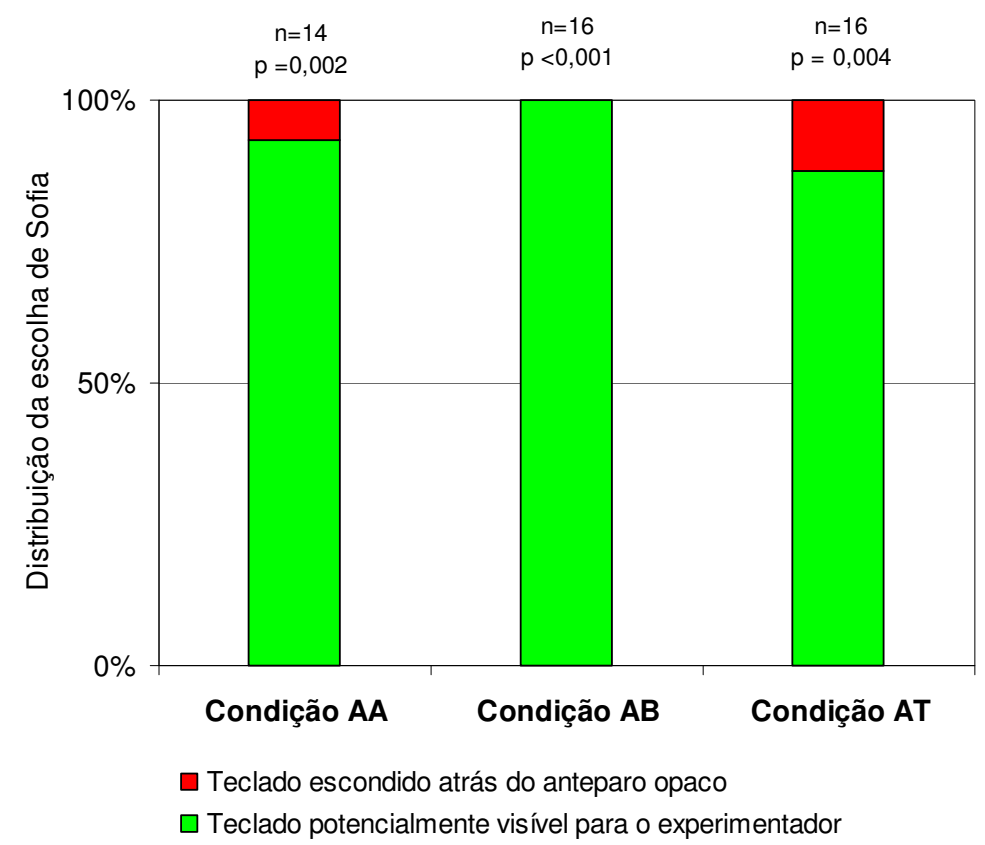

Figura 10. Distribuição da escolha de Sofia para as condições AA (anteparo alto), AB (anteparo baixo) e AT (anteparo baixo/anteparo transparente). Acima das barras encontram-se: o número de práticas utilizado no cálculo da proporção e o resultado do teste estatístico que avaliou se essa proporção era compatível com o acaso (50\%).

$\mathrm{Na}$ fase de generalização, observou-se que somente na sessão 6, com uma pessoa diferente do experimentador usual (Carine), Sofia escolheu o teclado escondido atrás do anteparo. Para todas as outras modificações propostas no cenário experimental Sofia continuou escolhendo o teclado potencialmente visível para o experimentador, até mesmo na situação mais próxima da natural, ao ar livre usando como o anteparo uma árvore, que representa o rompimento mais radical com a condição experimental controlada. Essa constatação indica que os resultados observados anteriormente não se restringem às condições experimentais controladas, e fortalece a hipótese de que Sofia, de fato, leva em conta o acesso visual do experimentador ao teclado ao usá-lo. 


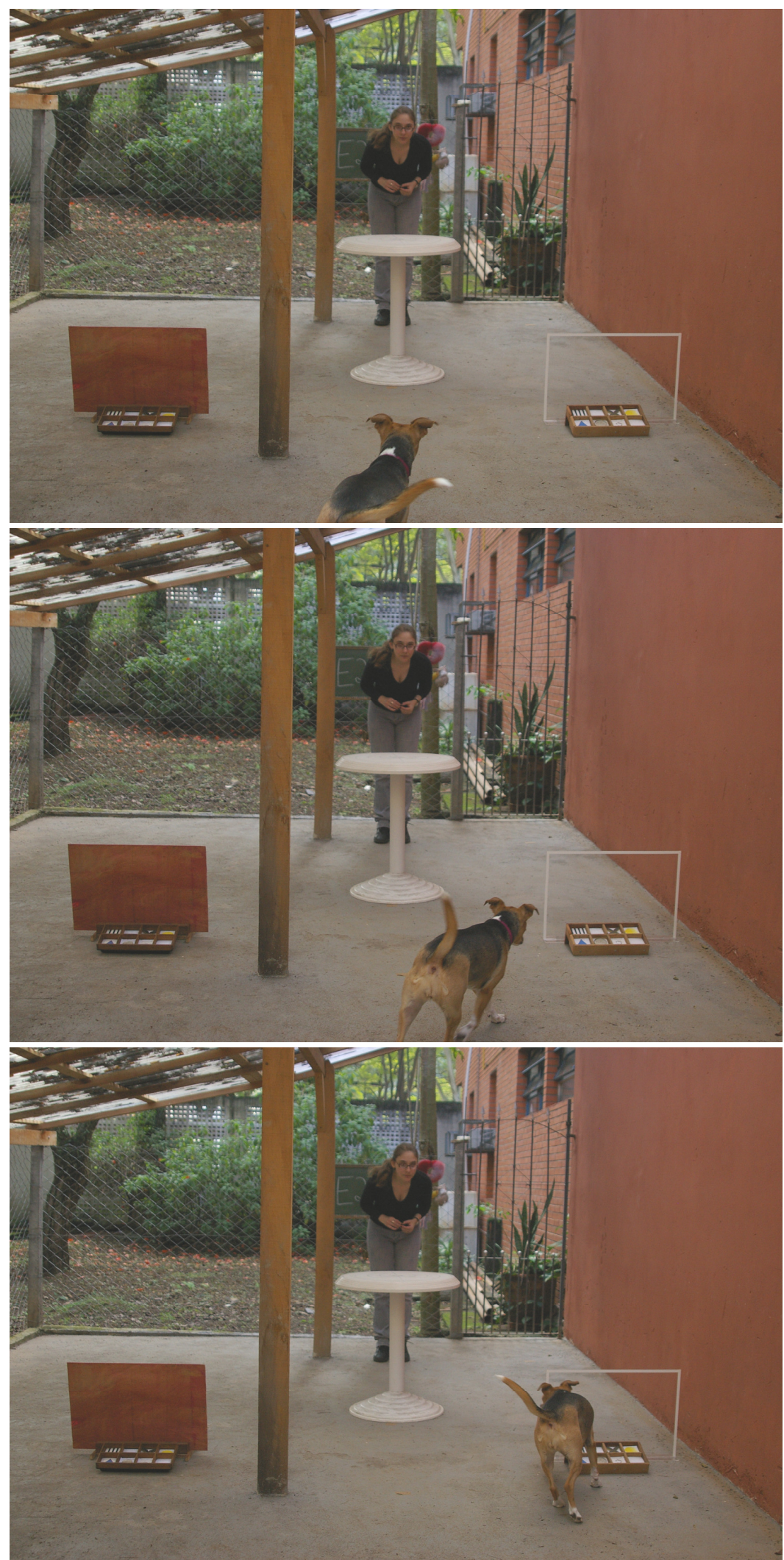

Figura 11. Seqüência de fotos que exemplificam a direção do olhar do experimentador e Sofia na condição experimental AT. 


\section{Condições OC e VO}

Já os resultados das condições OC e VO indicaram que a orientação corporal e a visibilidade dos olhos do ser humano não influenciaram a escolha de Sofia, uma vez que, ela escolheu ao acaso os teclados associados às condições com ou sem venda nos olhos, e, os teclados associados às posições frente e costas do ser humano ( $p=0,454$ e $\mathrm{p}=0,210$, respectivamente), conforme mostra a Figura 12.

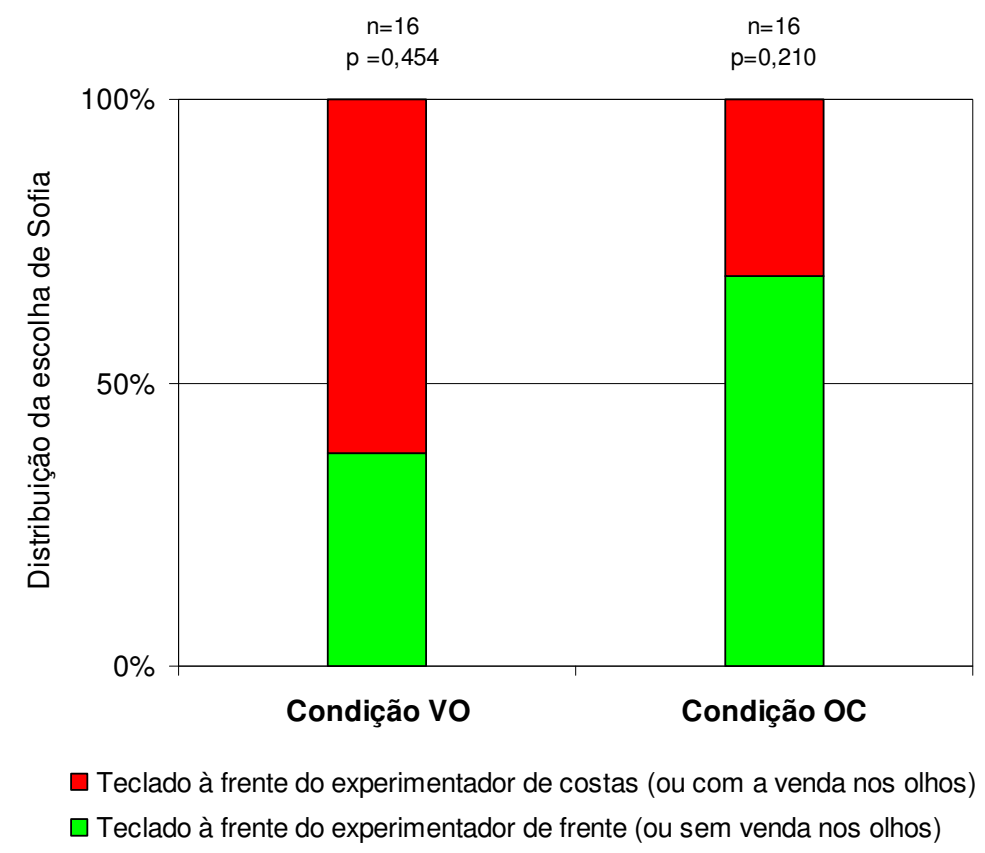

Figura 12. Distribuição da escolha de Sofia para as condições experimentais VO (visibilidade dos olhos), OC (orientação corporal). Acima das barras encontram-se: o número de práticas utilizado no cálculo da proporção e o resultado do teste estatístico que avaliou se essa proporção era compatível com o acaso (50\%).

\section{Condições OCexp e VOexp}

Nas condições OCexp e VOexp, em que se buscava saber se Sofia valoriza os sinais de atenção dos experimentadores no momento de receber o alimento pedido no teclado, 
constatou-se que Sofia preferiu receber seu pedido do experimentador que estava posicionado de frente acima do acaso $(\mathrm{p}<0,001)$, entretanto, a sua escolha entre as opções com e sem venda nos olhos foi compatível com o acaso $(p=0,210)$, como mostra a Figura 13.

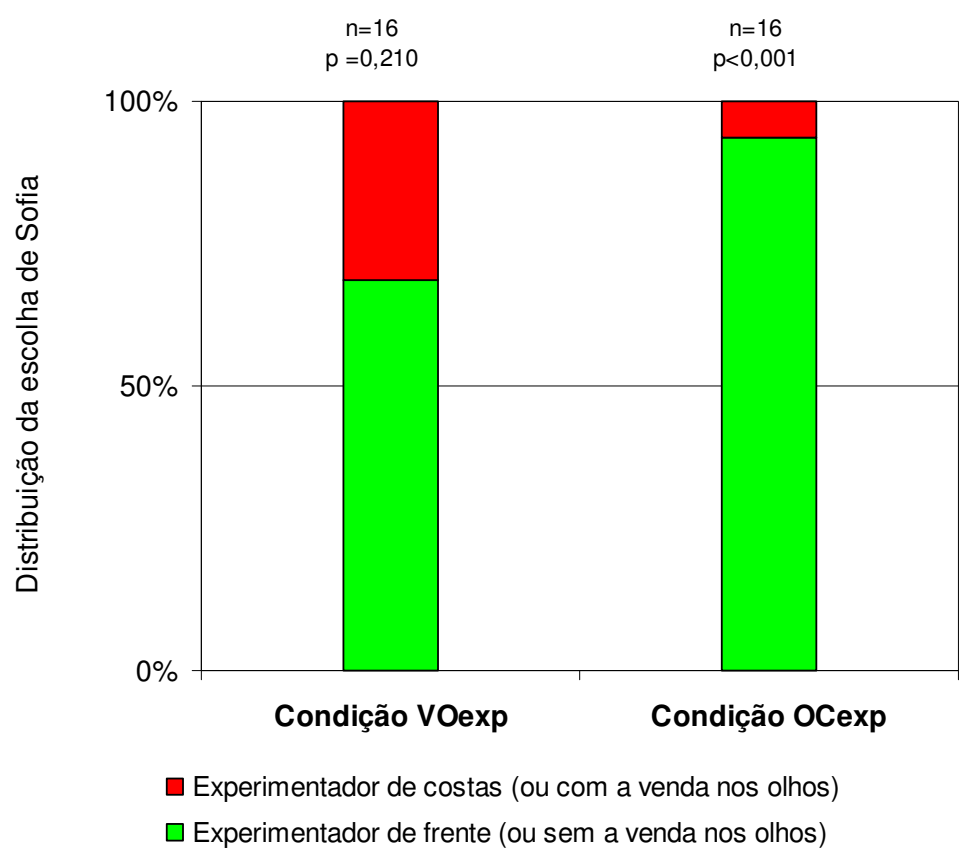

Figura 13. Distribuição da escolha de Sofia para as condições VOexp e OCexp. Acima das barras encontram-se: o número de práticas utilizado no cálculo da proporção e o resultado do teste estatístico que avaliou se essa proporção era compatível com o acaso (50\%). 


\section{DISCUSSÃO}

No trajeto evolutivo pelo qual um lobo ancestral foi adquirindo as características do cão doméstico, é muito provável que tenham sido adaptados e facilitados processos de comunicação (eventualmente já existentes na espécie silvestre) através dos quais sinais humanos são interpretados e atendidos pelo cão, e, através dos quais, o ser humano atende a necessidades do animal. Estes processos, que tornam possível a interação e a convivência estreitas, não são ainda plenamente compreendidos, do ponto de vista do modo como são adquiridos e postos em funcionamento. $\mathrm{O}$ uso de sistemas arbitrários de comunicação, como em nossa pesquisa, justamente por envolver novas aquisições e usos em relação à maneira como um cão espontaneamente interage com os seus donos, permite por em destaque aspectos relevantes da comunicação interespecífica.

Um destes aspectos é o papel da atenção do receptor - uma atenção direta, expressa por sinais de atenção (olhar para, estar de frente para, etc.) e a potencialidade de prestar atenção, indicada pela proximidade do receptor, pela ausência de barreiras, etc. - como modulador do comportamento de produção de sinais do cão.

No caso de Sofia, a produção de sinais não se restringe aos movimentos naturais (latir, correr em direção a, alternar olhares, etc.), utilizados como indicações cognitivas em estudos anteriores de cães. Ela se concretiza através do uso de uma interface, um teclado com lexigramas, cada um deles associado a um desejo ou motivação. No estudo anteriormente realizado com Sofia (Rossi \& Ades, 2008), verificou-se que as respostas 
de teclar não estavam associadas apenas à obtenção de um incentivo particular, como a gota d'água está relacionada à pressão à barra numa caixa de Skinner, mas sim que tinham o papel de atuar sobre um intermediário essencial, o ser humano. O aumento de olhares de Sofia para este (dirigidos para a região do rosto, muito provavelmente para os olhos) e a repetição do teclar, que ocorria sempre que o experimentador demorasse a agir, eram indicações claras de que teclar atuava como uma mensagem dirigida ao ser humano, um "mand" na acepção skinneriana. Mas o aumento da freqüência de olhares, depois de expresso um pedido no teclado, mesmo que indicasse a necessidade e relevância, para o cão, da proximidade do experimentador enquanto realizador de desejos, deixava sem esclarecer a importância da atenção explícita do experimentador como condição prévia, anteriormente à emissão de um pedido ao teclado. Em outras palavras, faltava entender o quanto era necessária para Sofia a obtenção ou a presença da atenção humana como condição para o uso de um lexigrama. A presença ou obtenção da atenção é, como já foi dito no início desta dissertação, um componente importante da comunicação entre seres humanos.

É verdade que, no experimento de Rossi \& Ades (2008), Sofia, muitas vezes olhava para Alexandre (o experimentador) antes de usar o teclado. Este olhar poderia ser interpretado, de um lado, como uma verificação da presença do experimentador, e também, de um estado de atenção dele, propício para a execução do pedido; de outro, como uma tentativa de obtenção de atenção. Mas a simples constatação destes olhares, prévios ao uso do teclado, não era indicação clara de que estivesse em jogo um processo de influência do estado de atenção do ser humano.

Para a obtenção de uma indicação confiável a respeito da influência da atenção humana para o início de um episódio de comunicação ao teclado é que, justamente, foram delineados os presentes experimentos. É importante ressaltar os cuidados tomados, nos 
experimentos, para evitar vieses. Quase todas as sessões ocorreram em dias diferentes, os experimentos eram programados em ordem aleatória em cada sessão. Não repetir a curto prazo o procedimento de determinado experimento e aleatorizar lados e teclados minimizava a dependência entre tentativas e garantia que os resultados não pudessem depender de aspectos acidentais de uma ou outra sessão.

Os resultados indicaram que:

(1) certos sinais de atenção humana (olhar humano exposto, posição do ser humano de frente para o cão) não são pré-condições necessárias para o emprego do teclado. Sofia usou ao acaso o teclado posicionado diante de um experimentador de olhos expostos (e olhando para ela) e o teclado posicionado diante de um experimentador de olhos vendados, da mesma forma que usou ao acaso os teclados diante dos experimentadores de frente e de costas.

(2) estes sinais de atenção podem, em contraposição, entrar em jogo num contexto em que Sofia, depois de ter feito o seu pedido no teclado, se dirige para um de dois experimentadores e escolhe acima do acaso um dentre eles para receber o alimento, o que está de frente para ela. É curioso que, neste caso, não tenha sido eficiente como modulador da escolha o sinal de atenção "olhos do experimentador visíveis" e que Sofia não tenha privilegiado o experimentador do qual via os olhos em relação ao que estava de olhos vendados.

(3) a visibilidade potencial de um teclado, pelo experimentador, isto é, o fato de não estar escondido atrás de um anteparo opaco, é um fator que propicia a sua escolha em relação a outro teclado ao qual o experimentador não tenha acesso visual. Este resultado é um argumento forte para a idéia de que Sofia leva em conta, na escolha de uma alternativa de comunicação, a percepção que tem de uma relação espacial (e talvez visual) entre o experimentador (que cumprirá o seu desejo) e o teclado. 
Discutiremos em sucessão estes três principais resultados do estudo.

\section{Os olhos e a orientação corporal do experimentador na escolha de um teclado}

Não cabe interpretar o resultado a partir do princípio de que Sofia, e cães em geral, não levam em conta, na sua interação com o ser humano, os olhos ou a posição frentecostas. Existem evidências de que pelo menos a orientação ou movimentação da cabeça e a posição frente-costas de pessoas influenciam o comportamento de cães. Entre estas está a demonstração de que: movimentar a cabeça acenando pode indicar ao cão o recipiente certo numa tarefa de escolha (Miklosi et al., 1998); o cão atenderá mais prontamente uma ordem quando o dono estiver de frente ou não distraído (Viranyi et al., 2004). Agnetta et al. (2000) não encontraram em cães a resposta de seguir o olhar do ser humano, mas verificaram o efeito paradoxal de que a direção do olhar humano gerava esquiva nos animais. O estudo de Call et al. (2003) é especialmente relevante por indicar que cães reagiram diferentemente (no caso de burlar uma ordem para não comer de um alimento disponível) quando o ser humano estava de olhos abertos ou fechados. Não se pode eliminar, portanto, a hipótese de que cães prestam atenção, dependendo do contexto, aos olhos (abertos ou fechados) de um ser humano. Cabe também lembrar que, no nosso próprio estudo, Sofia se mostrou sensível ao fator frente-costas no contexto de uma escolha entre experimentadores.

Uma segunda interpretação para os resultados negativos, no contexto da escolha de teclados, é que a rotina de teclar lexigramas para obter o que deseja, instalada por treino prévio, não se submete aos princípios de comunicação entre cão e ser humano e que ela apenas tem a função automática de gerar a recompensa ou de facilitar a sua obtenção, sem influência de uma percepção pelo cão do estado atencional do experimentador. $\mathrm{O}$ 
comportamento de Sofia, observado em inúmeras sessões, no presente estudo, mostra com nitidez estar centrado na pessoa do experimentador mesmo antes do uso do teclado. Uma terceira interpretação dos resultados negativos está relacionada com a história de treinamento de Sofia no uso do teclado. O teclado original empregado para este treinamento possuía, como mencionado, um dispositivo eletrônico que gerava a voz do experimentador (Alexandre Rossi) pronunciando a palavra correspondente ao lexigrama sempre que apertada a tecla. Embora testes (Rossi \& Ades, 2008) e o uso corriqueiro posterior tenham mostrado que Sofia discrimina visualmente os lexigramas, e que, é capaz de perfeitamente dispensar o feedback auditivo, é provável que tenha se estabelecido uma associação entre teclar e ouvir a palavra pronunciada. Na casa de sua atual dona, e, concomitantemente com os presentes experimentos, Sofia tinha acesso a um teclado "falante", e era atendida, mesmo que a sua dona não estivesse junto do teclado ou demonstrando atenção imediata. A rotina de obter atendimento através da produção sonora do teclado pode ter diminuído ou eliminado o controle exercido por sinais visuais de atenção das pessoas sobre o comportamento de Sofia e pode ter-se generalizado para o contexto dos testes experimentais, feitos sempre com teclado "mudo". Treinar um cão desde o começo com teclado "mudo" seria uma maneira de por a teste a presente interpretação: esse animal deveria ter maior sensibilidade aos sinais de atenção do dono, uma vez que nunca tivesse tido a oportunidade de se beneficiar de sinais acústicos.

Essa última interpretação remete a possibilidade de Sofia, ou de outros cães, perceber o valor de sinais acústicos (latir, por exemplo) para chamar a atenção de seus donos. Gaunet (2008) impediu cães guias de cegos de alcançarem um alimento que tinham aprendido a localizar. Os cães guias de cegos produziram (mais do que cães de companhia de donos com visão normal) um comportamento acústico novo: lambiam-se 
ruidosamente os beiços, talvez como maneira de sinalizar para donos sem visão. Os cães de cegos, contudo, não diferiram dos cães de companhia em outros comportamentos que envolvem o contato visual, como olhar para o dono, alternar olhares entre ele e o alimento desejado ou outras maneiras de chamar a atenção, como a vocalização. A autora conclui que os cães guias de cegos "não sabem que seus donos não podem vêlos”, mas que eles podem aprender sinais acústicos capazes de chamar sua atenção.

Um teste interessante a que Sofia poderia ser submetida seria permitir-lhe a escolha entre um teclado "mudo" e um teclado "falante", numa situação em que o experimentador estivesse dando toda a atenção visual ou estivesse de costas, ou longe do teclado, isto é, sem condições de prestar a devida atenção visual. O uso preferencial do teclado falante nesta segunda situação indicaria que Sofia conhece os efeitos de sons como sinais alternativos em condições de carência de contato percebido do dono com ela e com o teclado e mostraria a sua capacidade em discriminar sinais (positivos, negativos) de atenção do dono.

\section{Os olhos e a orientação corporal na escolha de um experimentador}

Como já mencionado, Sofia (depois de usar o teclado) escolheu de forma significativa, dentre os dois experimentadores capazes de lhe dar alimento, o que estava de frente. Este resultado se insere na série de resultados que indicam a sensibilidade de cães à posição do dono e decorre de uma prontidão que certamente se fortalece ao longo da ontogênese, através de muitos episódios de interação em que o animal descobre que o seu dono está mais disponível para a interação quando está numa posição face-à-face ou de frente (Gácsi et al., 2004; Viranyi et al. 2004). 
Escolher o experimentador situado de frente para ela torna imediato o contato visual de Sofia - olhos nos olhos - posterior ao uso do lexigrama, um contato visual que, como foi visto, ocorre freqüentemente no contexto de comunicação via teclado e que constitui justamente a característica que marca a presença de uma comunicação cão-ser humano genuína (Rossi \& Ades, 2008). A outra alternativa (experimentador de costas) não elimina de vez o contato visual, simplesmente o torna mais complicado e mais trabalhoso: Sofia poderia dar a volta ao experimentador até colocar-se de frente para ele, olhos nos olhos, um comportamento que muitos cães e Sofia também tem, em circunstâncias informais. Na condição dos experimentos prévios em que Sofia devia escolher entre um teclado mais próximo e outro mais distante do experimentador, quando Sofia escolhia pelo teclado mais distante, ela, em seguida, se direcionava para o experimentador buscando o contato visual, uma evidência a mais de que o contato visual com o experimentador, após o pedido expresso por lexigrama, é parte do processo e é valorizado por Sofia.

É mais intrigante a ausência de um resultado estatisticamente significativo no caso da escolha entre um experimentador com venda nos olhos e outro sem. Uma vez que cães parecem de fato dar importância ao olhar humano (Call et al., 2003) e o procuram sempre que olham para a face de pessoas, por que não manifestam esta percepção para distinguir uma pessoa com olhos expostos de outra com olhos cobertos?

Não cabe concluir, sem mais embasamento, que isto não ocorre porque cães não levam em conta o olhar humano enquanto sinal de atenção. Notou-se, durante os experimentos, que Sofia manifestava uma grande curiosidade, talvez até conflito, ao ser defrontada com uma pessoa vendada, uma percepção que diferia de tudo o que lhe tinha sido dado experienciar, no contato com seres humanos. Em alguns casos Sofia prolongava o seu olhar em direção ao experimentador vendado e alternava olhares entre a face deste 
experimentador e do outro com olhos visíveis, como se estivesse em conflito ou então comparando as faces. O estranhamento de Sofia diante de uma pessoa vendada poderia ter mascarado uma possível discriminação de sinais de atenção da face por simples escolha.

Gácsi et al. (2004) notam que, em situações habituais, como pedir a um cão que busque uma bola arremessada, uma mudança na brincadeira (por exemplo, quando o dono espera o cão trazer a bola de costas) pode deixar o animal confuso. $\mathrm{O}$ reconhecimento da atenção do ser humano pode ser influenciado pelos comportamentos que cães habitualmente executam e que os levam a uma percepção dos gestos e posturas do ser humano. Isso pode ter acontecido com Sofia na situação das condições OC e VO. Se Sofia tivesse sido testada numa situação mais natural (como, por exemplo, a de escolher entre uma pessoa de olhos fechados e outra de olhos abertos) talvez manifestasse uma preferência por quem pode enxergá-la.

\section{Anteparos e a visibilidade potencial do teclado}

O resultado que nos parece mais notável, na presente pesquisa, é a escolha consistente de Sofia pela alternativa do teclado visível (do ponto de vista do experimentador). Não é possível atribuí-la a um efeito de "Clever Hans", ou seja, a um viés decorrente de uma assimetria qualquer de posição e dos olhares do experimentador. $\mathrm{O}$ experimentador estava situado rigorosamente à mesma distância de ambos os teclados e mantinha os seus olhos sempre fixos em Sofia, desde o momento em que esta era liberada para fazer a sua escolha.

Vários controles experimentais eliminam explicações alternativas e tornam mais forte a interpretação de que a dimensão visível/não-visível é que orientava a escolha do animal. 
Essas explicações alternativas poderiam ser: (1) o anteparo interrompe a percepção que Sofia tem do experimentador, enquanto efetua a sua resposta de pressão ao lexigrama no teclado. Sofia poderia incomodar-se com o instante em que perderia a visão do experimentador se escolhesse o lado do anteparo alto. $\mathrm{O}$ anteparo baixo eliminou esta eventual interrupção de contato visual, mas não modificou a preferência pelo outro lado, sem anteparo; (2) o anteparo gera um pequeno atraso na ida de Sofia ao experimentador ou um desvio de rota em relação à alternativa sem anteparo. Embora o trajeto em direção ao experimentador, depois de teclar, fosse sempre muito rápido e direto, ao longo das práticas experimentais, ocorreu-nos que Sofia poderia ter a sua locomoção levemente desviada por conta da presença do anteparo, ou que, por um motivo não averiguado ela pudesse se incomodar com a existência de um anteparo, enquanto barreira física. $\mathrm{O}$ controle com um anteparo transparente, colocado simetricamente em relação ao outro opaco, elimina esta possibilidade. A consistência da escolha de Sofia, na condição AT, pelo lado do anteparo de acrílico, indica que seu comportamento não estava sendo controlado pela distinção anteparo $\times$ sem-anteparo, mas pela visibilidade enquanto tal.

Como interpretar esta clara preferência de Sofia pelo lado visível em relação ao lado não visível do ambiente? De acordo com uma primeira hipótese, a escolha do lado visível seria simplesmente devida à aprendizagem do lado em que não houvesse um anteparo, durante os experimentos prévios (uma condição equivalente à condição AA), aprendizagem essa que se generalizaria para as outras condições, AB e AT. Vários motivos tornam esta hipótese pouco plausível: (1) na fase de experimentos prévios, quando Sofia entrou em contato pela primeira vez com a situação de escolha anteparo $\times$ sem anteparo, ela escolheu mais freqüentemente o lado sem anteparo, e manteve a sua preferência, mesmo que, na maioria das vezes, não tenha recebido reforço. (2) o 
controle por generalização mostrou que a escolha pelo lado visível não estava associada às condições padronizadas de teste, ocorrendo de forma flexível diante de circunstâncias nunca antes experienciadas (como colocar o teclado não visível atrás de uma árvore) indicando a possível existência de uma estratégia básica de escolha; (3) embora estivesse em vigor o princípio de oferecer alimento depois de uma escolha "correta" também nas condições $\mathrm{OC}$ e $\mathrm{VO}$, um princípio que equivale ao reforço sistemático para uma de duas alternativas, não houve aquisição da escolha "certa" nesses casos, uma indicação de que o reforço não foi garantia, em nosso contexto experimental, para a aprendizagem de discriminação.

De acordo com uma segunda hipótese, formulada em termos cognitivos, Sofia (e outros cães) teriam uma compreensão da função da potencialidade de percepção visual em seres humanos, e uma compreensão de que objetos que impedem o acesso visual do ser humano e funcionam como anteparos representam uma condição para a emissão de comportamentos proibidos ou, ainda, para o não cumprimento de comandos humanos. O experimento de Brauer et al. (2004) é paradigmático, mostrando a capacidade do cão levar em conta o acesso visual do ser humano a uma comida proibida e a maior freqüência de transgressões quando um anteparo tornava impossível o acesso visual humano.

Esta interpretação não precisa necessariamente ser formulada em termos de uma "teoria da mente" canina. Não implica necessariamente que Sofia, ou outros cães, tenham uma representação da função dos olhos humanos e de que exista algo como "ver". Ela coloca, de maneira mais parcimoniosa, que existem sinais de atenção do ser humano e certas condições ambientais (posição do ser humano relativamente a anteparos, paredes, etc.) aos quais o cão presta uma atenção especial e que ele leva em conta, preditivamente, quando se trata de estabelecer uma interação e de pedir algo ao ser 
humano. A lógica deste processo preditivo seria algo como "regiões na frente do ser humano são regiões onde ele poderá reagir a algum comportamento meu, de pedir ou de transgredir" ou "a posição do ser humano atrás de um anteparo opaco o impede de reagir ou atrasa a reação a comportamentos meus". Um anteparo transparente não entraria na categoria de objeto que atrapalha o funcionamento da comunicação que o cão dirige ao ser humano. Nesta perspectiva, as capacidades de "leitura da atenção" de Sofia são menos amplas e gerais do que preveria uma concepção em termos de "teoria da mente”. São mais modulares e de domínio restrito. Assim, Sofia prefere usar um teclado que pode ser visto pelo experimentador, embora ela não tenha demonstrado compreensão a respeito da importância funcional de estarem abertos e sem vendas os olhos do experimentador, nem a respeito de sua orientação corporal, ao escolher o teclado a ser usado.

A origem da seletividade e da interpretação perceptuais em jogo no comportamento de Sofia pode residir no passado evolucionário e nas ações de domesticação às quais o ser humano submeteu os cães, e/ou, na experiência ontogenética de Sofia, na sua interação "aculturadora" com seres humanos.

Outros testes experimentais com Sofia e com outros cães são necessários para que seja maior a compreensão dos processos cognitivos em jogo na leitura dos sinais de atenção e do acesso visual do ser humano. Atualmente o laboratório de cães conta com mais uma cadela, Laila, sem raça definida e agora com 4 anos de idade, treinada para usar o teclado. Segundo relata sua proprietária, ela aprendeu a utilizar a tecla "comida" simplesmente observando Sofia usá-la. Agora conhece e usa os lexigramas para comida, água, brinquedo e passear. Laila foi submetida às condições experimentais pelas quais passou Sofia. Há diferenças individuais: Laila busca mais o olhar do ser humano do que Sofia e parece mais atenta aos sinais da atenção humana. 
Sofia voltará em breve a ser submetida a experimentos sobre sua compreensão do olhar humano e sobre as formas variadas de uso de sinais arbitrários ao teclado. Acreditamos que ela pode ainda nos dar muitas respostas sobre as capacidades cognitivas dos cães e sobre a sua comunicação com o ser humano. 


\section{APÊNDICE A}

Justificativa para determinação do número de repetições para cada condição experimental 
O objetivo de cada experimento foi verificar se a proporção de vezes que Sofia escolheu a condição de atenção do ser humano favorável para receber a informação do teclado era diferente do acaso (50\%). Uma vez que a pesquisa não pretendia treinar Sofia para diferenciar os estados de atenção e ausência de atenção, o número de repetições de cada experimento não poderia ser muito grande.

Para estudar a sensibilidade do teste estatístico fez-se um estudo de cálculo de tamanho de amostra variando-se a diferença a ser detectada entre a proporção de escolhas favoráveis à condição de atenção com relação ao acaso, e, fixando-se o nível de significância do teste Binomial em $5 \%$ e o poder de identificar a diferença de $90 \%$. A tabela abaixo resume esse estudo.

Tabela A.1 - Diferença percentual a ser detectada acima ou abaixo da proporção de escolha ao acaso (50\%) entre as condições de atenção e ausência de atenção, e, o número correspondente de repetições independentes necessário para tanto.

\begin{tabular}{cc}
\hline Diferença percentual a ser detectada & Número de repetições independentes \\
\hline $15 \%$ & 113 \\
$20 \%$ & 62 \\
$25 \%$ & 38 \\
$30 \%$ & 25 \\
$35 \%$ & 17 \\
$36 \%$ & 16 \\
\hline
\end{tabular}

A Tabela A.1 indica que para um nível de significância de 5\% e poder de $90 \%$ o número necessário de repetições independentes para considerar uma diferença significativa do acaso da magnitude de $36 \%$ é de $n=16$. Em outras palavras, com 16 repetições somente proporções de escolha da condição de atenção do ser humano favorável para receber a informação do teclado acima de $86 \%$ ou abaixo de $14 \%$ seriam consideradas diferentes 
do acaso (50\%). Um número de repetições menor que 16 dificultaria ainda mais detectar alguma diferença do acaso.

Como em todos os experimentos foi necessário contrabalançar algumas características binárias como posição dos teclados (esquerda/direita), posição dos experimentadores nas condições em que havia duas pessoas (esquerda/direita), posição do anteparo nas condições AA, AB e AT (esquerda/direita), orientação corporal e condição visual de cada experimentador nas condições OC, VO, OCexp e VOexp (frente/costas ou com/sem venda), optou-se por fazer um número de repetições múltiplo de 2 , portanto, 16 repetições. 


\section{APÊNDICE B}

Descrição do método de aleatorização utilizado para contrabalançar as características a serem controladas nos experimentos 


\section{Definição da ordem dos experimentos para a fase de testes}

Para definir a ordem em que as cinco condições experimentais (AA, AB, OC, VO OCexp+VOexp) deveriam ocorrer em cada sessão utilizou-se um procedimento de aleatorização em blocos. Ou seja, todas as possíveis permutações das cinco condições experimentais foram consideradas (120 possibilidades ao todo) e dessas 120 possibilidades foram selecionadas aleatoriamente 16, cada uma delas correspondendo à ordenação de cada sessão.

Definição do cenário para cada experimento.

$\Rightarrow$ Condição AA, AB e AT

As características a serem contrabalançadas ao longo das 16 sessões nessas condições experimentais foram:

- Posição do anteparo (direita/esquerda)

- Posição do teclado original (direita/esquerda)

As 4 possíveis combinações dessas características estão listadas na Tabela B.1. Todas as possíveis permutações das 4 combinações foram listadas ( 24 possibilidades ao todo) e entre elas foram selecionadas aleatoriamente 4 blocos (de 4 sessões cada), perfazendo um total 16 sessões. Assim, a cada 4 sessões todas as combinações foram contempladas em ordem aleatória e ao final todas elas ocorreram com a mesma freqüência. 
Tabela B.1 - Possíveis combinações das características a serem contrabalançadas nas condições experimentais com anteparo.

\begin{tabular}{ccc}
\hline Combinação & Posição do anteparo & Posição do teclado original* \\
\hline 1 & Direita & Direita \\
2 & Direita & Esquerda \\
3 & Esquerda & Direita \\
4 & Esquerda & Esquerda \\
\hline
\end{tabular}

*A posição do teclado novo era oposta à do teclado original.

$\Rightarrow$ Condição OC e VO

As características a serem contrabalançadas ao longo de 16 sessões na condição experimental OC foram:

- Posição do experimentador E1 (direita/esquerda)

- Posição do teclado original (direita/esquerda)

- Condição do experimentador E1 (frente/costas).

As 8 possíveis combinações dessas características estão listadas na Tabela B.2. De todas as possíveis permutações dessas 8 combinações foram selecionados 2 blocos (de 8 sessões cada), perfazendo um total 16 sessões. Assim, a cada 8 sessões todas as combinações foram contempladas em ordem aleatória, e, ao final todas elas ocorreram com a mesma freqüência.

O procedimento para definir o cenário de cada sessão na condição VO foi o mesmo que o descrito para a condição OC. 
Tabela B.2 - Possíveis combinações das características a serem contrabalançadas ao longo das sessões na condição experimental OC.

\begin{tabular}{ccc}
\hline $\begin{array}{c}\text { Posição do } \\
\text { experimentador E1* }\end{array}$ & $\begin{array}{c}\text { Posição do teclado } \\
\text { original** }\end{array}$ & $\begin{array}{c}\text { Condição do } \\
\text { experimentador E1*** }\end{array}$ \\
\hline Direita & Direita & Frente \\
Direita & Direita & Costas \\
Direita & Esquerda & Frente \\
Direita & Esquerda & Costas \\
Esquerda & Direita & Frente \\
Esquerda & Direita & Costas \\
Esquerda & Esquerda & Frente \\
Esquerda & Esquerda & Costas \\
\hline
\end{tabular}

*A posição do experimentador E2 era oposta à de E1.

**A posição do teclado novo era oposta à do teclado original.

*** A condição do experimentador E2 era oposta à condição de E1.

\section{$\Rightarrow$ Condição OCexp+VOexp}

Nessa condição experimental as 16 sessões foram divididas entre as duas condições testadas e, portanto, a condição também foi uma característica considerada na definição do cenário. Assim, as características a serem contrabalançadas ao longo das 16 sessões nessa condição experimental foram:

- Condição experimental (OCexp ou VOexp)

- Posição do experimentador E1 (direita/esquerda)

- Condição de E1 (frente ou costas; com ou sem venda).

Novamente, de todas as possíveis permutações das oito combinações listadas na Tabela B.3 foram selecionados 2 blocos (de 8 sessões cada), perfazendo um total 16 sessões. Assim, a cada 8 sessões todas as combinações foram contempladas e ao final todas elas ocorreram com a mesma freqüência. 
Tabela B.3 - Possíveis combinações das características a serem contrabalançadas ao longo das sessões nas condições OCexp+VOexp.

\begin{tabular}{ccc}
\hline Condição & $\begin{array}{c}\text { Posição do } \\
\text { experimentador E1* }\end{array}$ & $\begin{array}{c}\text { Condição do } \\
\text { experimentador E1** }\end{array}$ \\
\hline VOexp & Direita & Com \\
VOexp & Direita & Sem \\
VOexp & Esquerda & Com \\
VOexp & Esquerda & Sem \\
OCexp & Direita & Frente \\
OCexp & Direita & Costas \\
OCexp & Esquerda & Frente \\
OCexp & Esquerda & Costas \\
\hline
\end{tabular}

*A posição do experimentador E2 era oposta à de E1.

** A condição do experimentador E2 era oposta à condição de E1. 
APÊNDICE C

Dados coletados 
Condição AA

\begin{tabular}{|c|c|c|c|c|c|c|}
\hline DATA & Condição & Sessão & Lado Anteparo & $\begin{array}{c}\text { Lado Teclado } \\
\text { original }\end{array}$ & $\begin{array}{c}\text { Utilizou } \\
\text { Teclado }\end{array}$ & $\begin{array}{c}\text { Teclado } \\
\text { escolhido }\end{array}$ \\
\hline $22 / 01 / 2008$ & AA & 1 & Direita & Esquerda & S & Visível \\
\hline $23 / 01 / 2008$ & AA & 2 & Esquerda & Direita & S & Visível \\
\hline $24 / 01 / 2008$ & AA & 3 & Esquerda & Esquerda & S & Visível \\
\hline $28 / 01 / 2008$ & AA & 4 & Direita & Direita & S & Visível \\
\hline $30 / 01 / 2008$ & AA & 5 & Direita & Esquerda & N & - \\
\hline $31 / 01 / 2008$ & AA & 6 & Esquerda & Esquerda & S & Visível \\
\hline $01 / 02 / 2008$ & AA & 7 & Esquerda & Direita & N & - \\
\hline $01 / 02 / 2008$ & AA & 8 & Direita & Direita & S & Visível \\
\hline $07 / 02 / 2008$ & AA & 9 & Esquerda & Direita & S & Visível \\
\hline $07 / 02 / 2008$ & AA & 10 & Direita & Esquerda & S & Visível \\
\hline $08 / 02 / 2008$ & AA & 11 & Direita & Direita & S & Visível \\
\hline $11 / 02 / 2008$ & AA & 12 & Esquerda & Esquerda & S & Visível \\
\hline $20 / 02 / 2008$ & AA & 13 & Direita & Esquerda & S & Visível \\
\hline $22 / 02 / 2008$ & AA & 14 & Esquerda & Esquerda & S & Visível \\
\hline $22 / 02 / 2008$ & AA & 15 & Direita & Direita & S & Visível \\
\hline $25 / 02 / 2008$ & AA & 16 & Esquerda & Direita & S & Anteparo \\
\hline
\end{tabular}

Condiçãa AB

\begin{tabular}{|c|c|c|c|c|c|c|}
\hline DATA & Condição & Sessão & $\begin{array}{c}\text { Lado } \\
\text { Anteparo }\end{array}$ & $\begin{array}{c}\text { Lado do teclado } \\
\text { original }\end{array}$ & Utilizou teclado & $\begin{array}{c}\text { Teclado } \\
\text { escolhido }\end{array}$ \\
\hline $22 / 01 / 2008$ & $\mathrm{AB}$ & 1 & Direita & Direita & $\mathrm{S}$ & Visível \\
\hline $23 / 01 / 2008$ & $\mathrm{AB}$ & 2 & Direita & Esquerda & $\mathrm{S}$ & Visível \\
\hline $24 / 01 / 2008$ & $\mathrm{AB}$ & 3 & Esquerda & Direita & $\mathrm{S}$ & Visível \\
\hline $28 / 01 / 2008$ & $\mathrm{AB}$ & 4 & Esquerda & Esquerda & $\mathrm{S}$ & Visível \\
\hline $30 / 01 / 2008$ & $\mathrm{AB}$ & 5 & Direita & Esquerda & $\mathrm{S}$ & Visível \\
\hline $31 / 01 / 2008$ & $\mathrm{AB}$ & 6 & Esquerda & Direita & $\mathrm{S}$ & Visível \\
\hline $01 / 02 / 2008$ & $\mathrm{AB}$ & 7 & Esquerda & Esquerda & $\mathrm{S}$ & Visível \\
\hline $01 / 02 / 2008$ & $\mathrm{AB}$ & 8 & Direita & Direita & $\mathrm{S}$ & Visível \\
\hline $07 / 02 / 2008$ & $\mathrm{AB}$ & 9 & Direita & Direita & $\mathrm{S}$ & Visível \\
\hline $07 / 02 / 2008$ & $\mathrm{AB}$ & 10 & Esquerda & Direita & $\mathrm{S}$ & Visível \\
\hline $08 / 02 / 2008$ & $\mathrm{AB}$ & 11 & Esquerda & Esquerda & $\mathrm{S}$ & Visível \\
\hline $11 / 02 / 2008$ & $\mathrm{AB}$ & 12 & Direita & Esquerda & $\mathrm{S}$ & Visível \\
\hline $20 / 02 / 2008$ & $\mathrm{AB}$ & 13 & Direita & Esquerda & $\mathrm{S}$ & Visível \\
\hline $22 / 02 / 2008$ & $\mathrm{AB}$ & 14 & Esquerda & Esquerda & $\mathrm{S}$ & Visível \\
\hline $22 / 02 / 2008$ & $\mathrm{AB}$ & 15 & Direita & Direita & $\mathrm{S}$ & Visível \\
\hline $25 / 02 / 2008$ & $\mathrm{AB}$ & 16 & Esquerda & Direita & $\mathrm{S}$ & Visível \\
\hline
\end{tabular}


Condição VO

\begin{tabular}{|c|c|c|c|c|c|c|c|}
\hline DATA & Condição & Sessão & $\begin{array}{c}\text { Lado do } \\
\text { teclado } \\
\text { original }\end{array}$ & $\begin{array}{c}\text { Lado do } \\
\text { Experimentador } \\
\text { E1 }\end{array}$ & $\begin{array}{c}\text { Venda de } \\
\text { E1 }\end{array}$ & $\begin{array}{c}\text { Utilizou } \\
\text { Teclado }\end{array}$ & $\begin{array}{c}\text { Escolha de } \\
\text { Sofia }\end{array}$ \\
\hline $22 / 01 / 2008$ & VO & 1 & Direita & Esquerda & Sem & S & Sem venda \\
\hline $23 / 01 / 2008$ & VO & 2 & Esquerda & Esquerda & Com & S & Com venda \\
\hline $24 / 01 / 2008$ & VO & 3 & Esquerda & Esquerda & Sem & S & Com venda \\
\hline $28 / 01 / 2008$ & VO & 4 & Esquerda & Direita & Sem & S & Com venda \\
\hline $30 / 01 / 2008$ & VO & 5 & Esquerda & Direita & Com & S & Com venda \\
\hline $31 / 01 / 2008$ & VO & 6 & Direita & Esquerda & Com & S & Sem venda \\
\hline $01 / 02 / 2008$ & VO & 7 & Direita & Direita & Sem & S & Com venda \\
\hline $01 / 02 / 2008$ & VO & 8 & Direita & Direita & Com & S & Sem venda \\
\hline $07 / 02 / 2008$ & VO & 9 & Esquerda & Direita & Com & S & Com venda \\
\hline $07 / 02 / 2008$ & VO & 10 & Direita & Esquerda & Com & S & Com venda \\
\hline $08 / 02 / 2008$ & VO & 11 & Direita & Direita & Com & S & Com venda \\
\hline $11 / 02 / 2008$ & VO & 12 & Esquerda & Esquerda & Com & S & Sem venda \\
\hline $20 / 02 / 2008$ & VO & 13 & Esquerda & Esquerda & Sem & S & Com venda \\
\hline $22 / 02 / 2008$ & VO & 14 & Direita & Direita & Sem & S & Sem venda \\
\hline $22 / 02 / 2008$ & VO & 15 & Esquerda & Direita & Sem & S & Sem venda \\
\hline $25 / 02 / 2008$ & VO & 16 & Direita & Esquerda & Sem & S & Com venda \\
\hline
\end{tabular}

\section{Condição OC}

\begin{tabular}{|c|c|c|c|c|c|c|c|}
\hline DATA & Condição & Sessão & $\begin{array}{c}\text { Lado do } \\
\text { teclado } \\
\text { original }\end{array}$ & $\begin{array}{c}\text { Lado do } \\
\text { Experimentador } \\
\text { E1 }\end{array}$ & $\begin{array}{c}\text { Orientação } \\
\text { de E1 }\end{array}$ & $\begin{array}{c}\text { Utilizou } \\
\text { Teclado }\end{array}$ & $\begin{array}{c}\text { Escolha de } \\
\text { Sofia }\end{array}$ \\
\hline $22 / 01 / 2008$ & OC & 1 & Esquerda & Esquerda & Costas & S & Frente \\
\hline $23 / 01 / 2008$ & OC & 2 & Direita & Direita & Costas & S & Frente \\
\hline $24 / 01 / 2008$ & OC & 3 & Esquerda & Direita & Frente & S & Frente \\
\hline $28 / 01 / 2008$ & OC & 4 & Direita & Esquerda & Frente & S & Frente \\
\hline $30 / 01 / 2008$ & OC & 5 & Esquerda & Esquerda & Frente & S & Frente \\
\hline $31 / 01 / 2008$ & OC & 6 & Direita & Direita & Frente & S & Costas \\
\hline $01 / 02 / 2008$ & OC & 7 & Esquerda & Direita & Costas & S & Costas \\
\hline $01 / 02 / 2008$ & OC & 8 & Direita & Esquerda & Costas & S & Frente \\
\hline $07 / 02 / 2008$ & OC & 9 & Esquerda & Esquerda & Frente & S & Costas \\
\hline $07 / 02 / 2008$ & OC & 10 & Direita & Esquerda & Frente & S & Costas \\
\hline $08 / 02 / 2008$ & OC & 11 & Esquerda & Direita & Costas & S & Frente \\
\hline $11 / 02 / 2008$ & OC & 12 & Esquerda & Direita & Frente & S & Frente \\
\hline $20 / 02 / 2008$ & OC & 13 & Direita & Esquerda & Costas & S & Frente \\
\hline $22 / 02 / 2008$ & OC & 14 & Direita & Direita & Costas & S & Costas \\
\hline $22 / 02 / 2008$ & OC & 15 & Esquerda & Esquerda & Costas & S & Frente \\
\hline $25 / 02 / 2008$ & OC & 16 & Direita & Direita & Frente & S & Frente \\
\hline
\end{tabular}




\section{Condição VOexp+OCexp}

\begin{tabular}{|c|c|c|c|c|c|c|c|}
\hline DATA & Fase & Sessão & Condição & \begin{tabular}{|c|} 
Lado do \\
experimentador \\
E1 \\
\end{tabular} & $\begin{array}{c}\text { Condição } \\
\text { de E1 }\end{array}$ & $\begin{array}{l}\text { Utilizou } \\
\text { teclado }\end{array}$ & $\begin{array}{c}\text { Escolha de } \\
\text { Sofia } \\
\end{array}$ \\
\hline $09 / 04 / 2007$ & Pré-teste & 1 & VOexp & Direita & Com & $\mathrm{S}$ & Sem venda \\
\hline $09 / 04 / 2007$ & Pré-teste & 2 & OCexp & Esquerda & Costas & $S$ & Frente \\
\hline $10 / 04 / 2007$ & Pré-teste & 3 & OCexp & Direita & Frente & $\mathrm{S}$ & Frente \\
\hline $16 / 04 / 2007$ & Pré-teste & 4 & OCexp & Esquerda & Costas & $\mathrm{S}$ & Frente \\
\hline $16 / 04 / 2007$ & Pré-teste & 5 & VOexp & Direita & Com & $\mathrm{S}$ & Sem venda \\
\hline $16 / 04 / 2007$ & Pré-teste & 6 & VOexp & Esquerda & Sem & $\mathrm{S}$ & Sem venda \\
\hline $19 / 04 / 2007$ & Pré-teste & 7 & OCexp & Direita & Frente & $S$ & Frente \\
\hline $23 / 04 / 2007$ & Pré-teste & 8 & VOexp & Esquerda & Sem & $\mathrm{S}$ & Com venda \\
\hline $23 / 04 / 2007$ & Pré-teste & 9 & VOexp & Direita & Com & $S$ & Sem venda \\
\hline $24 / 04 / 2007$ & Pré-teste & 10 & VOexp & Esquerda & Sem & $\mathrm{S}$ & Sem venda \\
\hline $03 / 05 / 2007$ & Pré-teste & 11 & OCexp & Direita & Frente & $S$ & Frente \\
\hline $08 / 05 / 2007$ & Pré-teste & 12 & OCexp & Esquerda & Costas & $\mathrm{S}$ & Frente \\
\hline $08 / 05 / 2007$ & Pré-teste & 13 & VOexp & Direita & Com & $\mathrm{S}$ & Sem venda \\
\hline $14 / 05 / 2007$ & Pré-teste & 14 & VOexp & Esquerda & Sem & $\mathrm{S}$ & Sem venda \\
\hline $15 / 05 / 2007$ & Pré-teste & 15 & OCexp & Esquerda & Costas & $\mathrm{S}$ & Frente \\
\hline $28 / 05 / 2007$ & Pré-teste & 16 & OCexp & Direita & Frente & $S$ & Costas \\
\hline $22 / 01 / 2008$ & Teste & 1 & OCexp & Esquerda & Costas & $\mathrm{S}$ & Frente \\
\hline $23 / 01 / 2008$ & Teste & 2 & VOexp & Esquerda & Sem & $\mathrm{S}$ & Sem venda \\
\hline $24 / 01 / 2008$ & Teste & 3 & VOexp & Direita & Com & $S$ & Com venda \\
\hline $28 / 01 / 2008$ & Teste & 4 & VOexp & Direita & Com & $\mathrm{S}$ & Sem venda \\
\hline $30 / 01 / 2008$ & Teste & 5 & OCexp & Direita & Frente & $S$ & Frente \\
\hline $31 / 01 / 2008$ & Teste & 6 & VOexp & Esquerda & Sem & $\mathrm{S}$ & Sem venda \\
\hline $01 / 02 / 2008$ & Teste & 7 & OCexp & Esquerda & Costas & $\mathrm{S}$ & Frente \\
\hline $01 / 02 / 2008$ & Teste & 8 & OCexp & Direita & Frente & $\mathrm{S}$ & Frente \\
\hline $07 / 02 / 2008$ & Teste & 9 & OCexp & Direita & Frente & $\mathrm{S}$ & Frente \\
\hline $07 / 02 / 2008$ & Teste & 10 & VOexp & Direita & Com & $S$ & Sem venda \\
\hline $08 / 02 / 2008$ & Teste & 11 & OCexp & Esquerda & Costas & $\mathrm{S}$ & Frente \\
\hline $11 / 02 / 2008$ & Teste & 12 & OCexp & Esquerda & Costas & $\mathrm{S}$ & Frente \\
\hline $20 / 02 / 2008$ & Teste & 13 & OCexp & Direita & Frente & $\mathrm{S}$ & Frente \\
\hline $22 / 02 / 2008$ & Teste & 14 & VOexp & Direita & Com & $S$ & Com venda \\
\hline $22 / 02 / 2008$ & Teste & 15 & VOexp & Esquerda & Sem & $\mathrm{S}$ & Com venda \\
\hline $25 / 02 / 2008$ & Teste & 16 & VOexp & Esquerda & Sem & $\mathrm{S}$ & Com venda \\
\hline
\end{tabular}


Condição AT

\begin{tabular}{|c|c|c|c|c|c|c|}
\hline DATA & Condição & Sessão & $\begin{array}{c}\text { Lado Anteparo } \\
\text { Opaco }\end{array}$ & $\begin{array}{c}\text { Lado Painel } \\
\text { original }\end{array}$ & $\begin{array}{c}\text { Utilizou } \\
\text { painel }\end{array}$ & $\begin{array}{c}\text { Teclado escolhido } \\
\text { atrás do anteparo }\end{array}$ \\
\hline $10 / 03 / 2008$ & AT & 1 & Esquerda & Esquerda & S & Transparente \\
\hline $14 / 03 / 2008$ & AT & 2 & Esquerda & Direita & S & Opaco \\
\hline $19 / 03 / 2008$ & AT & 3 & Direita & Esquerda & S & Transparente \\
\hline $24 / 03 / 2008$ & AT & 4 & Direita & Direita & S & Transparente \\
\hline $26 / 03 / 2008$ & AT & 5 & Direita & Direita & S & Transparente \\
\hline $28 / 03 / 2008$ & AT & 6 & Esquerda & Direita & S & Transparente \\
\hline $31 / 03 / 2008$ & AT & 7 & Esquerda & Esquerda & S & Transparente \\
\hline $02 / 04 / 2008$ & AT & 8 & Direita & Esquerda & S & Transparente \\
\hline $04 / 04 / 2008$ & AT & 9 & Direita & Esquerda & $\mathrm{S}$ & Transparente \\
\hline $08 / 04 / 2008$ & AT & 10 & Esquerda & Esquerda & $\mathrm{S}$ & Transparente \\
\hline $14 / 04 / 2008$ & AT & 11 & Direita & Direita & $\mathrm{S}$ & Transparente \\
\hline $16 / 04 / 2008$ & AT & 12 & Esquerda & Direita & $\mathrm{S}$ & Transparente \\
\hline $23 / 04 / 2008$ & AT & 13 & Esquerda & Direita & $\mathrm{S}$ & Transparente \\
\hline $25 / 04 / 2008$ & AT & 14 & Esquerda & Esquerda & $\mathrm{S}$ & Transparente \\
\hline $28 / 04 / 2008$ & AT & 15 & Direita & Esquerda & $\mathrm{S}$ & Transparente \\
\hline $30 / 04 / 2008$ & AT & 16 & Direita & Direita & $\mathrm{S}$ & Opaco \\
\hline
\end{tabular}




\section{REFERÊNCIAS BIBLIOGRÁFICAS}

ADES, C.; RAMOS, D.; \& ROSSI, A. P. (2003). The comprehension and production of arbitrary signals by a domestic dog, Sofia. XXVIII International Ethological Conference, Florianópolis, Brazil. Revista de Etologia (Suplemento), 5, 61.

ADES, C.; ROSSI, A. P.; PINSETA, D. (2000). Em Santos, C. V.; Vieira, M. L. (Org.) Anais do XVIII Encontro Anual de Etologia (pp. 213). Florianópolis: Sociedade Brasileira de Etologia.

AGNETTA, B.; HARE, B. \& TOMASEllO, M. (2000). Cue to food location that domestic dogs (Canis familiaris) of different ages do and do not use. Animal Cognition, $3,107-112$.

BRAUER, J.; CALL, J. \& TOMASELLO, M. (2004). Visual perspective taking in dogs (Canis familiaris) in the presence of a barrier. Applied Animal Behavior Science, 88, 299-317.

CALL, J.; BRAUER, J.; KAMINSKI, J. \& TOMASELLO, M. (2003). Domestic dogs (Canis familiaris) are sensitive to the attentional state of humans. Journal of Comparative Psychology, 117, 257-263.

DOUGLAS, K. (2000). Mind of a dog. New Scientist, 23-27. 
FOUTS, R. S. \& MELLGREN, R. L. (1976). Language, signs and cognition in the chimpanzee. Sign language studies, 13, 319-346.

GÁCSI, M.; MIKLÓSI, A.; VARGA, O.; TOPÁL, J. \& CSÁNYI, V. (2004). Are readers of our face readers of our minds ? Dogs (Canis familiaris) show situationdependent recognition of human's attention. Animal Cognition, 7, 144-153.

GÁCSI, M.; KARA, E.; BELÉNYI, B.; TOPÁL, J. \& MIKLÓSI, A. (2007). Effects of selection for cooperation and attention? News perspectives on evaluating dogs' performance in human point test (submitted).

GARDNER, R. A. \& GARDNER, B. T. (1971). Two-way communication with an infant chimpanzee. In A. M. Schrier \& F. Stollnitz (Eds). Behavior of nonhuman primates, vol. 4, New York: Academic.

GAUNET, F. (2008). How guide-dogs of blind owners and pet dogs of sighted owners (Canis familiaris) ask their owners for food ?. Animal Cognition, 11, 475-483.

HAYES, K. J.; HAYES, C. (1951). The intellectual development of a home-raised chimpanzee. Proceedings of of the American Philosofical Society, 95, 105-109.

HARE, B.; CALL, J. \& TOMASELLO, M. (1998). Communication and food location between human and dogs (Canis familiaris). Evolution of communication, 2, 137, 159.

HARE, B. \& TOMASELLO, M. (1999). Domestic dogs use human and conspecific social cues to locate hidden food. Journal of Comparative Psychology, 113, 173.

HARE, B.; BROWN, M.; WILlIAMSON, C. \& TOMASELLO, M. (2002). The domestication of social cognition in dogs. Science, 298, 1634-1636. 
HARE, B. \& TOMASELLO, M. (2005). Human-like social skills in dogs? Trends in Cognitive Science, 9, 405-454.

KAMINSKI, J.; CALL, J. \& TOMASELLO, M. (2004). Body orientation and face orientation: two factors controlling ape's begging behavior from humans. Animal Cognition, 7, 216-223.

KAMINSKI, J.; CALL, J. \& FISCHER, J. (2004). Word learning in a domestic dog: Evidence for "Fast mapping”. Science, 304, 1682-1683.

KAMINSKI, J. (2008). Dogs' Understanding of Human Forms of Communication. Proceedings of Canine Science Forum, pg 61.

KELlOGG, W. N. \& KELlOGG, L. A. (1933) apud Savege-Rumbaugh et al. (1993).

KUBINYI, E.; VIRÁNYI, Z. \& MIKLÓSI, A. (2007). Comparative Social Cognition: from wolf and dog to humans. Comparative cognition \& behavior reviews, 2, 26-46.

MIKLÓSI, A.; POLGÁRDI, R.; TOPÁL, J. \& CSÁNYI, V. (1998). Use of experimenter-given cues in dogs. Animal Cognition, 1, 113-128.

MIKLÓSI, A.; POLGÁRDI, R.; TOPÁL，J. \& CSÁNYI，V. (2000). Intentional behaviour in dog-human communication: an experimental analysis of "showing" behaviour in the dog. Animal Cognition, 3(3), 159-166.

MIKLÓSI, A.; KUBINYI, E.; TOPÁL, J.; GÁCSI, M.; VIRÁNYI, Zs. \& CSÁNYI, V. (2003). A simple reason for a big difference: wolves do not look back at humans but dogs do. Current Biology, 13, 763-766. 
MIKLÓSI, A.; TOPÁL, J. \& CSÁNYI, V. (2004). Comparative Social Cognition: what can dogs teach us. Animal Behavior, 67, 995-1004.

MIKLÓSI, A. \& SOPRONI, K. (2006). Comprehension of the human pointing gesture in animals: A comparative approach. Animal Cognition, 9, 81-93.

MIKLÓSI, A. (2007). Dog behaviour, Evolution and Cognition. Oxford University press.

PEPPERBERG, I. M. (1981). Functional vocalizations by an african grey parrot (Psittacus erithacus). Zeitschrift fur Tierpsychologie, 55, 139-160.

PEPPERBERG, I. M. (1991). A Communicative Approach to Animal Cognition: A Study of Conceptual Abilities of an African Grey Parrot. .Em: Ristau, C. A. Cognitive Ethology: the minds of other animal. L Erbaum Associates, 153-155.

PEPPERBERG, I. M. (1999). Rethinking syntax: A commentary on E. Kako's "Elements of syntax in the systems of three language-trained animals." Animal Learning and Behavior, 27(1), 15-17.

PONGRÁCZ, P.; MIKLÓSI, A.; KUBINYI, E.; GUROBI, K.; TOPÁL, J. \& CSÁNYI, V. (2001). Social learning in dogs: the effect of human demonstrator on the performance of dogs in a detour task. Animal Behavior, 62, 1109-1117.

PONGRÁCZ, P.; MIKLÓSI, A.; TIMÁR-GENG, K. \& CSÁNYI, V. (2004). Verbal attention getting as a key factor in social learning between dog (Canis familiaris) and human. Journal of Comparative Psychology, 118, 375-383. 
POVINELLI, D. J. \& EDDY, T. J. (1996). What chimpanzees know about seeing. Monogr Soc Res Child Dev, 61-152.

POVINELLI, D. J.; BIERSCHWALE, D.T. \& CECH, C.G. (1999). Comprehension of seeing as a referential act in young children, but not juvenile chimpanzees. British Journal of Developmental Psychology, 17, 37-60.

RAMOS, D.; ROSSI, A. P. \& ADES, C. (2003). Discrimination of multiple sign commands by a dog. XXVIII International Ethological Conference, Florianópolis, Brazil. Revista de Etologia (Suplemento), 5, p. 196.

RIEDEL, J.; SCHUMANN, K.; KAMINSKI, J.; CALL, J. \& TOMASELLO, M. (2008). The early ontogeny of human-dog communication. Animal Behaviour, 75, $1003-1014$

ROSSI, A. P. (2004). Comunicação cão-homem através de sinais arbitrários. Dissertação de Mestrado IP/USP, São Paulo.

ROSSI, A. P. \& ADES, C. (2008). A dog at the keyboard: using arbitrary signs to communicate requests. Animal Cognition. doi:10.1007/s10071-007-0122-3.

SAVAGE-RUMBAUGH, E. S. (1984). Verbal Behavior at a procedural level in the chimpanzee. Journal of Experimental Analysis of Behavior, 41, 223-250.

SAVAGE-RUMBAUGH, E. S.; MCDONALD, K.; SEVCIK, R. A.; HOPKINS, W. D. \& RUBERT, E. (1986). Spontaneous symbol acquisition and communicative use by pygmy chimpanzees (Pan paniscus). Journal of Experimental Psychology, 115(3), 211235. 
SAVAGE-RUMBAUGH, E. S.; MURPHY, J.; SEVCIK, R. A.; BRAKKE, K.; WILLIAMS, S. L. \& RUMBAUGH, D. M. (1993). Language comprehension in ape and child. Monographs of the society for research in child development, serial n. 233, vol. 58, n. 3-4.

SAVAGE-RUMBAUGH, S. \& LEWIN, R. (1994). Kanzi. The ape at the brink of the human mind. John Wiley \& Sons, Inc: Canada.

SERPELL, J. E. (1995). The domestic dog: its evolution, behavior and interaction with people. Cambridge University press, Cambridge.

SOPRONI, K.; MIKLOSI, A.; TOPÁL, J. \& CSÁNYI, V. (2001). Comprehension of human communicative signs in pet dogs (Canis familiaris). Journal of Comparative Psychology, 115(2), 122-126.

SOPRONI, K.; MIKLOSI, A.; TOPÁL, J. \& CSÁNYI, V. (2002). Dogs responsiveness to human point gesture. Journal of Comparative Psychology, 116, 27-34.

TOPÁL, J.; GÁCSI, M.; MIKLOSI, A.; VIRÁNYI, Zs; KUBINYI, E. \& CSÁNYI, V. (2005a). The effect of domestication and socialization on attachment to human: A comparative study on hand reared wolves and differently socialized dog puppies. Animal Behaviour, 70, 1367-1375.

TOPÁL, J.; KUBINYI, E. \& GÁCSI et al (2005b). Obeying social rules: A comparative study on dogs and humans. Journal of Cultural and Evolutionary Psychology, 3, 213238. 
TOPÁL, J.; ERDOREGYI, Á.; MÁNYIK, R. et al (2006a). Mindreading in a dog: an adaptation of a primate "mental attribution" study. International Journal of Psychology and Psychological therapy, 6, 365-379.

TOPÁL, J.; BYRNE, R.W. \& MIKLÓSI, A. (2006b). Reproducing human actions and action sequences: "Do as I do!” in a dog. Animal Cognition, 9, 355-367.

UDELL, M. A. R.; DOREY, N. R. \& WYNNE, C. D. L. (2008). Wolves outperform dogs in following human social cues. Animal Behaviour, doi: 10.1016/j.anbehav.2008.07.028.

VILÁ C.; SAVOLAINEN, P.; MALDONADO, J. E.; AMORIM I. R.; RICE, J. E.; HONEYCUTT, R. L.; CANDRALL K. A.; LUNDEBERG, J.; WAYNE, R. K. (1997). Multiple and ancient origins of the domestic dog. Science, 276, 1687-1689.

VIRÁNYI, Z.; TOPÁL, J.; GÁCSI, M.; MIKLOSI, A. \& CSÁNYI, V. (2004). Dogs respond appropriately to cues of human's attentional focus. Behavioural Processes, 66, 161-172.

VIRÁNYI, Z.; TOPÁL, J., MIKLÓSI, A. \& CSÁNYI, V. (2006). A non-verbal test of knowledge attribution: a comparative study on dogs and children. Animal Cognition, 9, $13-26$.

VIRÁNYI, Z.; GÁCSI, M. \& KUBINYI, E. (2007). Comprehension of human point gestures in young human-reared wolves and dogs. Animal Cognition (in press).

WYNNE, C. D. L.; UDELL, M. A. R. \& LORD, K. A. (2008). Ontogeny’s impacts on human-dog communication. Animal Behaviour, doi: 10.1016/j.anbehav.2008.03.010. 